Supporting Information for:

\title{
An Experimentally Derived Model for Stereoselectivity in the Aerobic Oxidative Kinetic Resolution of Secondary Alcohols by (sparteine) $\mathbf{P d C l}_{2}$
}

\author{
Raissa M. Trend and Brian M. Stoltz*
}

The Arnold and Mabel Beckman Laboratories of Chemical Synthesis, Division of Chemistry and Chemical

Engineering, California Institute of Technology, Pasadena, California 91125, USA

\section{TABLE OF CONTENTS}

Page

$\begin{array}{ll}\text { Figures and Schemes Reproduced From the Text } & \text { S2 }\end{array}$

$\begin{array}{ll}\text { Stereo Views of Molecular Structures } & \text { S5 }\end{array}$

$\begin{array}{ll}\text { Experimental Section } & \text { S10 }\end{array}$

Tabulation of Palladium Alkoxide Complexes Bearing $\beta$-Hydgrogens $\quad$ S15

$\begin{array}{ll}\text { Molecular Structures and Crystallographic Data for } \mathbf{1} & \text { S16 }\end{array}$

$\begin{array}{ll}\text { Molecular Structures and Crystallographic Data for } 2 & \text { S19 }\end{array}$

$\begin{array}{ll}\text { Molecular Structures and Crystallographic Data for } 4 & \text { S22 }\end{array}$

$\begin{array}{lr}\text { Molecular Structures and Crystallographic Data for } 6 & \text { S25 }\end{array}$

$\begin{array}{lr}\text { Molecular Structures and Crystallographic Data for S02 } & \text { S28 }\end{array}$ 


\section{FIGURES AND SCHEMES REPRODUCED FROM THE TEXT}

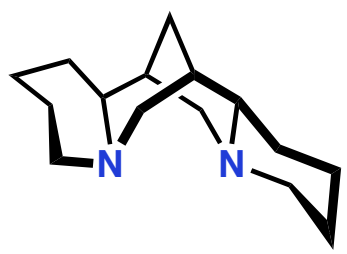

(-)-sparteine

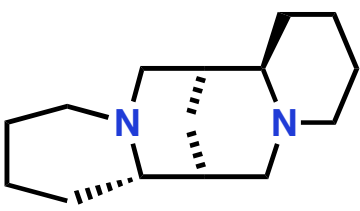

front view side view

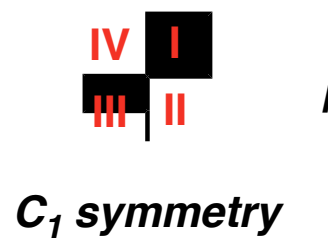

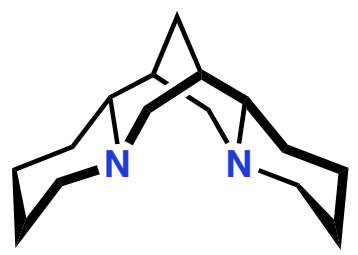

(-)- $\alpha$-isosparteine

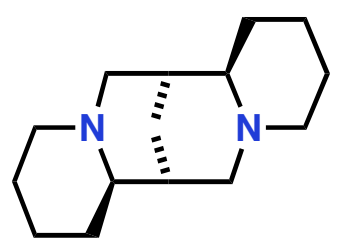

quadrant perspective

$C_{2}$ symmetry
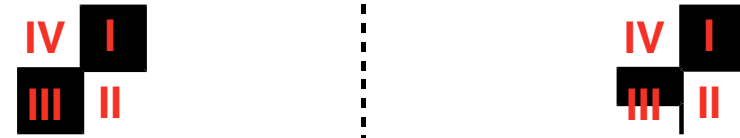

$C_{1}$ symmetry

Figure 1. Three perspectives of (-)-sparteine, (-)- $\alpha$-isosparteine, and (sp) $\mathrm{PdCl}_{2}$ showing the $C_{1}$ and $C_{2}$ symmetry of these ligands and the quaternization effect around the metal center. Molecular structure of $\mathbf{1}$ is shown with $50 \%$ probability ellipsoids. Hydrogens from the sp framework in the front view have been removed for clarity.

\section{Scheme 1}
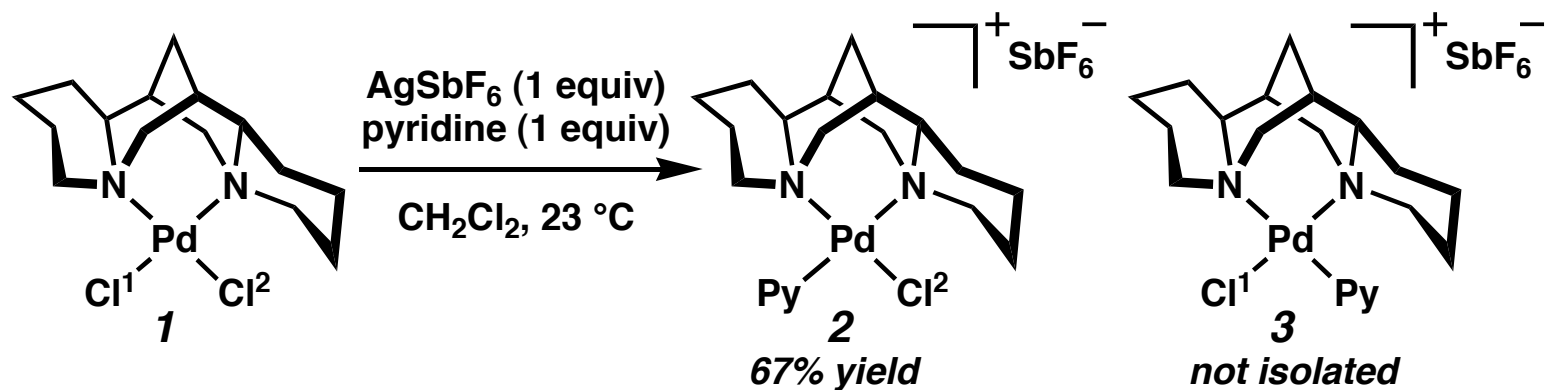
<smiles>Cc1cc(C)c(-c2ccccn2)c(C)c1</smiles>

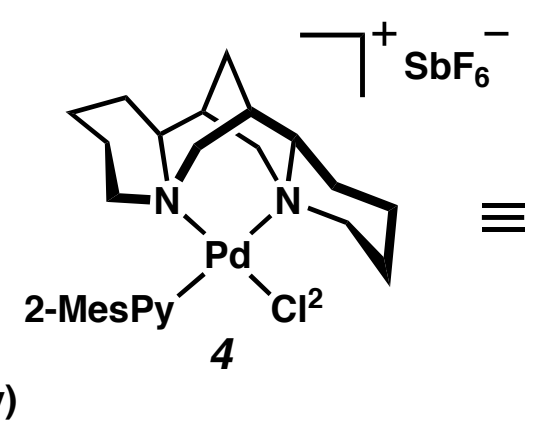

\section{1}
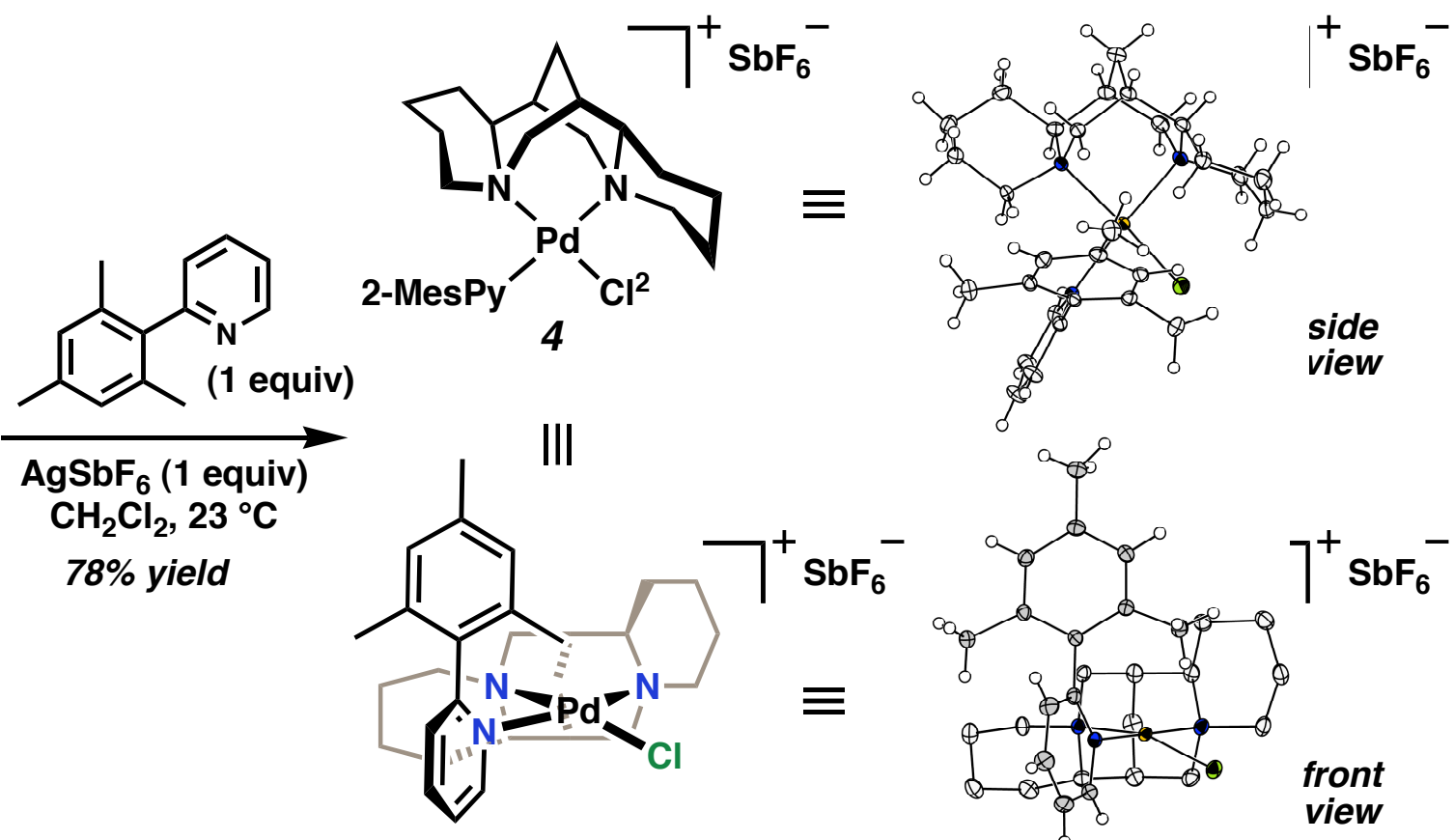

\section{Scheme $3^{1}$}<smiles>O[C@H](c1ccccc1)C(F)(F)F</smiles>

$(+)-5$ (1 equiv) $\mathrm{NaH}$ (1 equiv) THF, $23^{\circ} \mathrm{C}$

$62 \%$ yield

\begin{tabular}{c|c} 
Atoms & Distance $(\AA)$ \\
\hline $\mathrm{Pd}-\mathrm{N}^{1}$ & $2.1243(17)$ \\
$\mathrm{Pd}-\mathrm{N}^{2}$ & $2.0925(16)$ \\
$\mathrm{Pd}-\mathrm{O}$ & $2.0012(14)$ \\
$\mathrm{Pd}-\mathrm{Cl}$ & $2.3316(5)$ \\
\hline $\mathrm{N}^{1}-\mathrm{Pd}-\mathrm{Cl}$ angle $=164.59(5)^{\circ}$
\end{tabular}

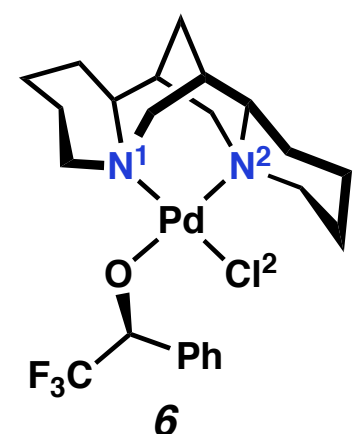

6

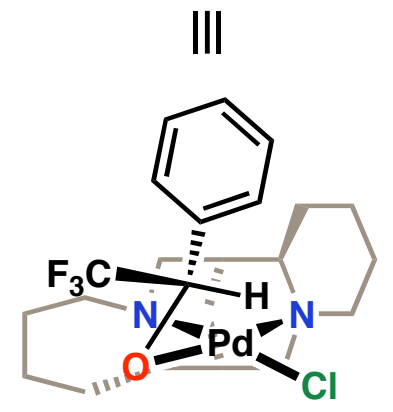

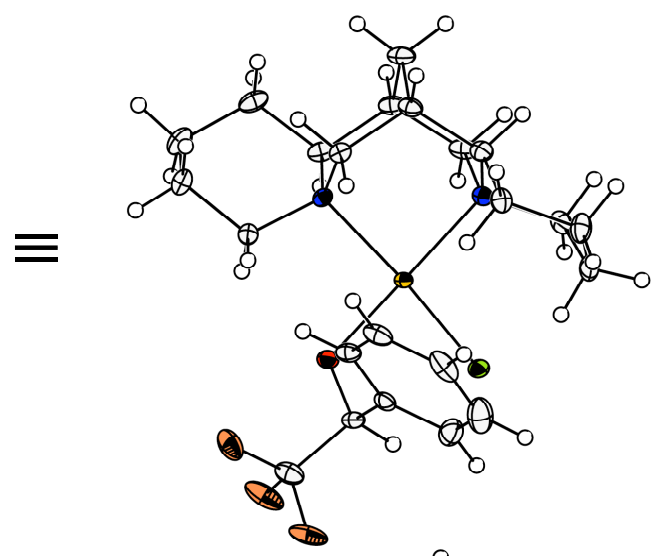

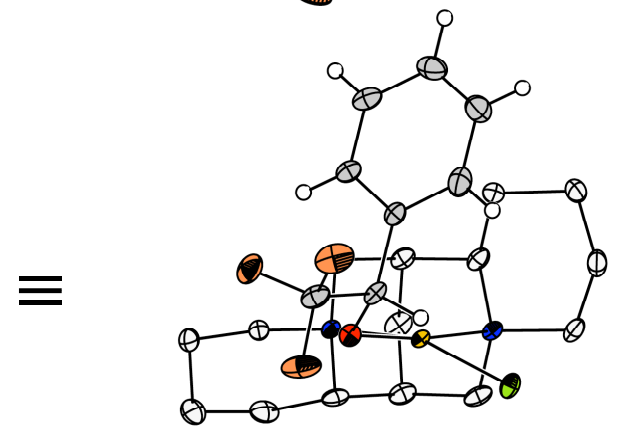

${ }^{1}$ Molecular structures of $\mathbf{4}$ and $\mathbf{6}$ are shown with $50 \%$ probability ellipsoids. Hydrogens from the $\mathrm{sp}$ framework in the front view and the anion of $\mathbf{4}$ have been removed for clarity. 


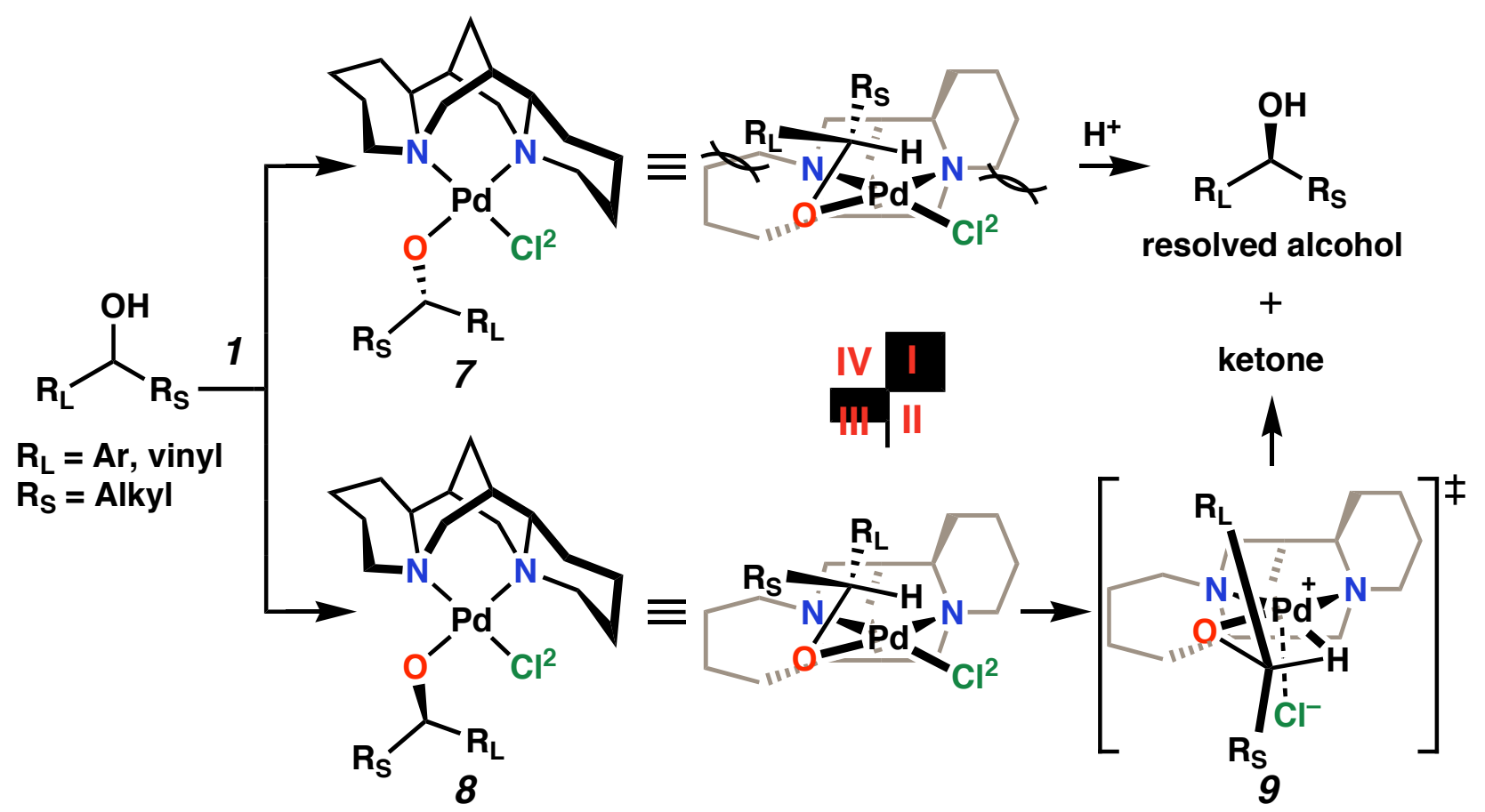

Figure 2. A model for stereoselectivity in the Pd catalyzed aerobic oxidative kinetic resolution using (sp) $\mathrm{PdCl}_{2}$. 


\section{STEREO VIEWS OF MOLECULAR STRUCTURES}

Figure S01. Stereo side view of (sparteine) $\mathrm{PdCl}_{2}$ (1). Molecular structure shown with $50 \%$ probability ellipsoids. Solvent molecules $\left(\mathrm{CDCl}_{3}\right)$ have been omitted for clarity.
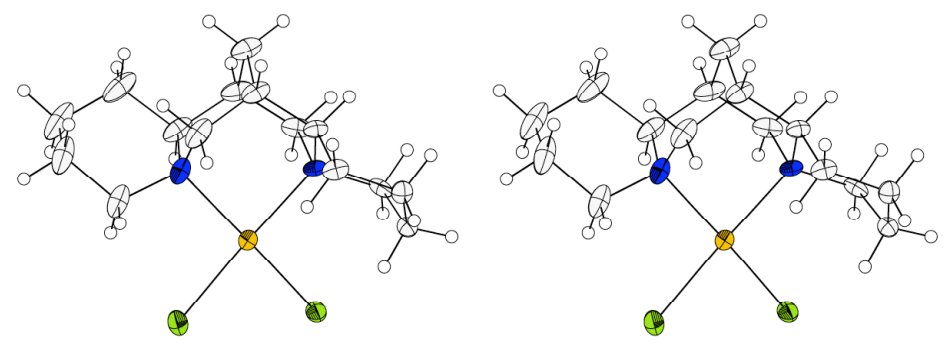

Figure S02. Stereo front view of (sparteine) $\mathrm{PdCl}_{2}(\mathbf{1})$. Molecular structure shown with $50 \%$ probability ellipsoids. Hydrogen atoms and solvent molecules $\left(\mathrm{CDCl}_{3}\right)$ have been omitted for clarity.
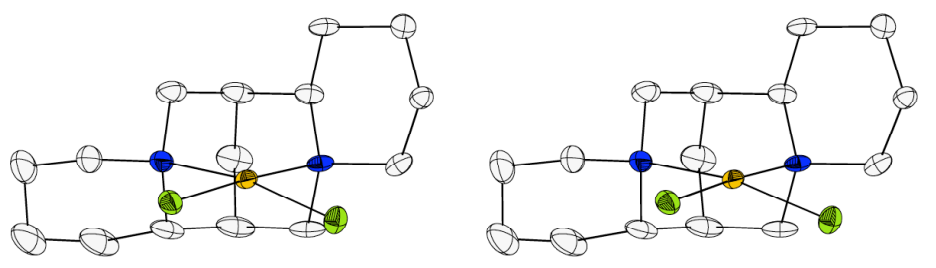


\section{STEREO VIEWS OF MOLECULAR STRUCTURES, CONT'D}

Figure S03. Stereo side view of $[(\text { sparteine }) \mathrm{Pd}(\text { pyridine }) \mathrm{Cl}]^{+} \mathrm{SbF}_{6}{ }^{-}$(2). Molecular structure shown with $50 \%$ probability ellipsoids. The anion has been omitted for clarity.
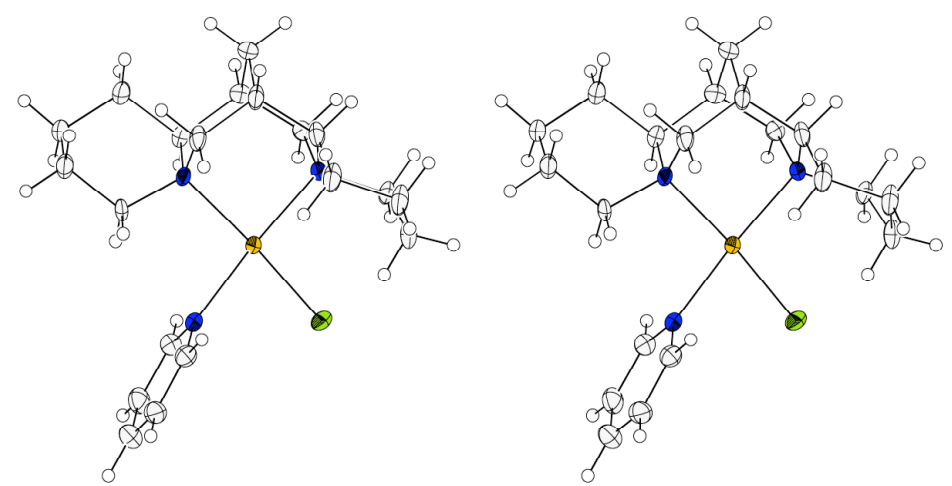

Figure S04. Stereo front view of [(sparteine) $\mathrm{Pd}($ pyridine $) \mathrm{Cl}^{+} \mathrm{SbF}_{6}^{-}$(2). Molecular structure shown with 50\% probability ellipsoids. Hydrogen atoms in the sparteine ligand and the anion have been omitted for clarity.
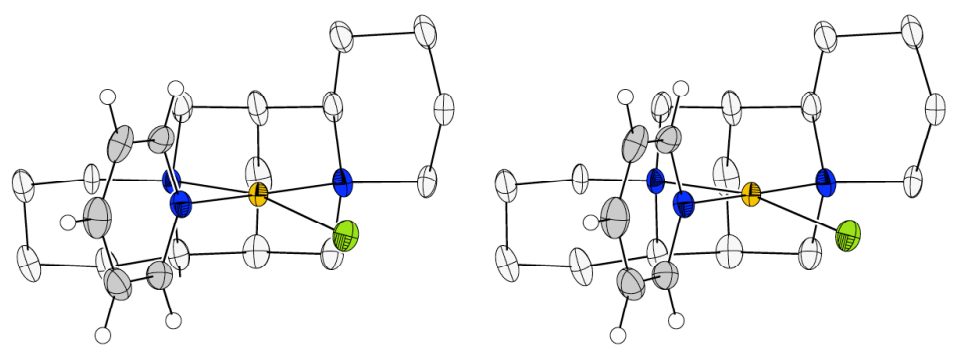


\section{STEREO VIEWS OF MOLECULAR STRUCTURES, CONT'D}

Figure S05. Stereo side view of $\left[\right.$ (sparteine) $\mathrm{Pd}(2-$ mesitylpyridine $) \mathrm{Cl}^{+} \mathrm{SbF}_{6}^{-}$(4). Molecular structure shown with $50 \%$ probability ellipsoids. The anion has been omitted for clarity.
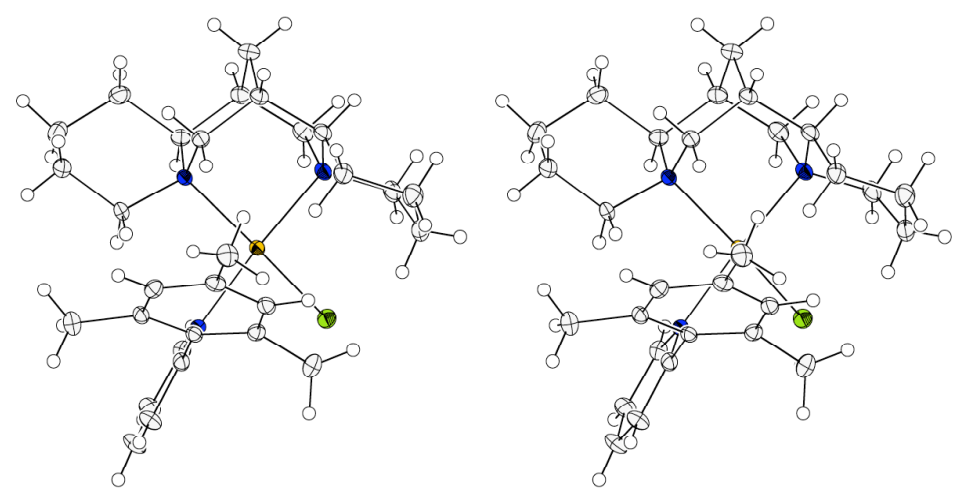

Figure S06. Stereo front view of [(sparteine) $\mathrm{Pd}(2-$ mesitylpyridine $) \mathrm{Cl}^{+} \mathrm{SbF}_{6}^{-}(4)$. Molecular structure shown with $50 \%$ probability ellipsoids. Hydrogen atoms in the sparteine ligand and the anion have been omitted for clarity.
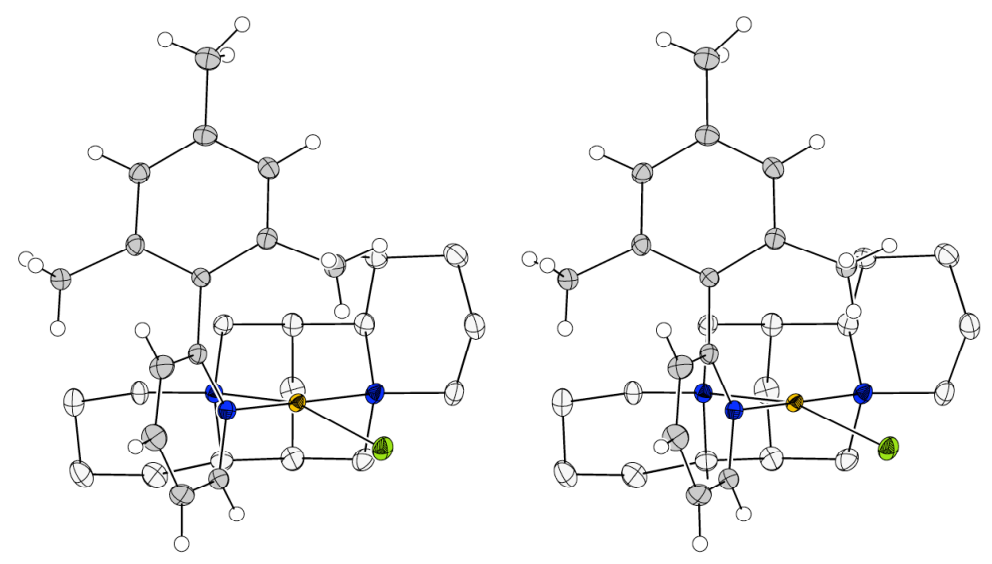


\section{STEREO VIEWS OF MOLECULAR STRUCTURES, CONT'D}

Figure S07. Stereo side view of (sparteine) $\mathrm{Pd}\left(\mathrm{OCH}_{(}\left(\mathrm{CF}_{3}\right) \mathrm{C}_{6} \mathrm{H}_{5}\right) \mathrm{Cl}(\mathbf{6})$. Molecular structure shown with $50 \%$ probability ellipsoids. Solvent molecules $\left(\mathrm{CH}_{2} \mathrm{Cl}_{2}\right)$ have been omitted for clarity.
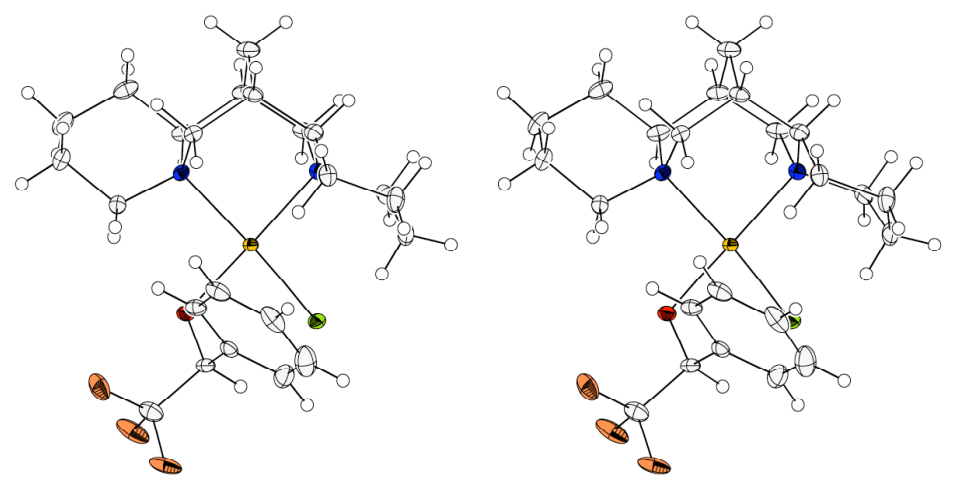

Figure S08. Stereo front view of (sparteine) $\mathrm{Pd}\left(\mathrm{OCH}\left(\mathrm{CF}_{3}\right) \mathrm{C}_{6} \mathrm{H}_{5}\right) \mathrm{Cl}(\mathbf{6})$. Molecular structure shown with $50 \%$ probability ellipsoids. Hydrogen atoms in the sparteine ligand and solvent molecules $\left(\mathrm{CH}_{2} \mathrm{Cl}_{2}\right)$ have been omitted for clarity.

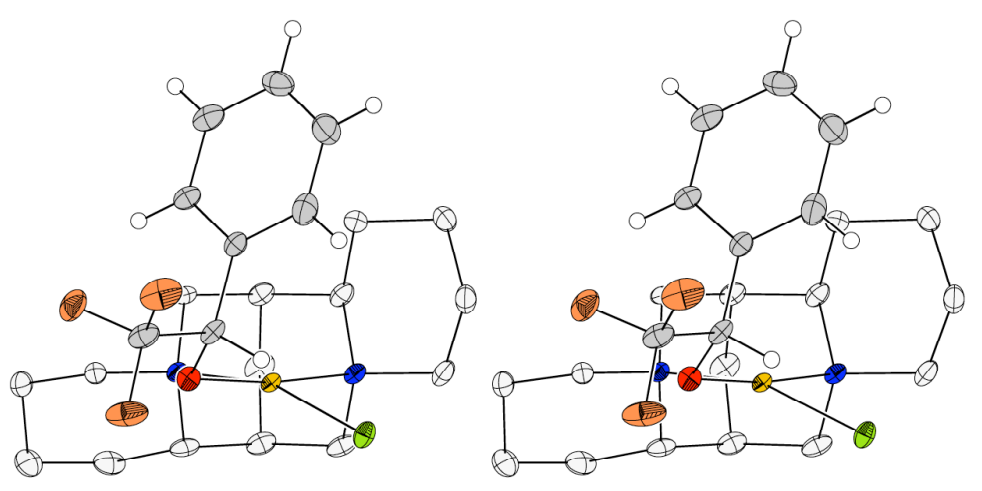




\section{STEREO VIEWS OF MOLECULAR STRUCTURES, CONT'D}

Figure S09. Stereo side view of ( $\alpha$-isosparteine) $\mathrm{PdCl}_{2}(\mathbf{S 0 2})$. Molecular structure shown with $50 \%$ probability ellipsoids.
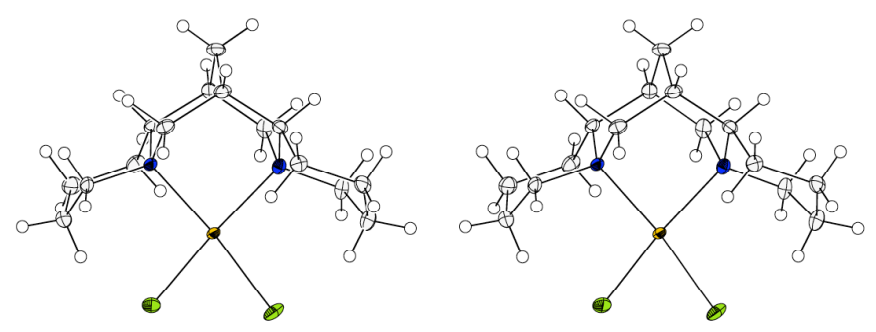

Figure S10. Stereo top view of ( $\alpha$-isosparteine) $\mathrm{PdCl}_{2}$ (S02). Molecular structure shown with $50 \%$ probability ellipsoids. Hydrogen atoms in the sparteine ligand have been omitted for clarity.
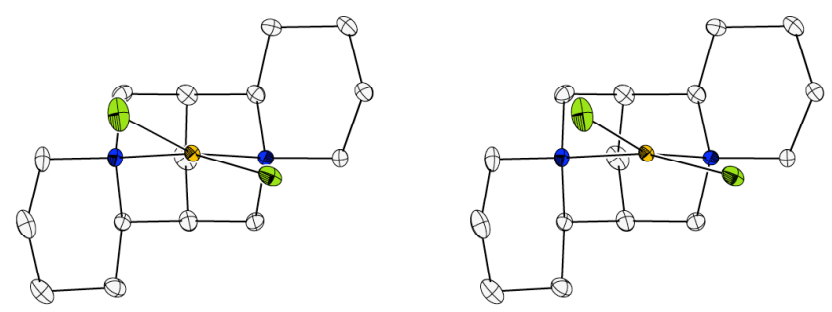


\section{EXPERIMENTAL SECTION}

Materials and Methods. Unless stated otherwise, reactions were conducted in oven-dried glassware under an argon atmosphere with freshly distilled solvents using standard Schlenk techniques. Although we have never experienced an accident, all reactions must be performed with appropriate caution in a fume hood due to the flammable nature of mixtures of oxygen and organic solvents. All commercially obtained reagents were used as received. Reaction temperatures were controlled by an IKAmag temperature modulator. Thin-layer chromatography (TLC) was conducted with E. Merck silica gel 60 F254 precoated plates $(0.25 \mathrm{~mm})$ and visualized via UV and anisaldehyde staining. ICN silica gel (particle size $0.032-0.063 \mathrm{~mm}$ ) was used for flash column chromatography. Analytical chiral HPLC was performed on a Chiralcel OJ column (4.6 mm x 25 $\mathrm{cm}$ ) obtained from Daicel Chemical Industries, Ltd. Analytical achiral GC was carried out on an Agilent DB-WAX column (30.0 m x $0.25 \mathrm{~mm})$ purchased from Bodman Industries. Organic reagents were purchased from the Sigma-Aldrich Chemical Company, Milwaukee, WI and metal salts obtained from Strem Chemicals, Newburyport, MA. ${ }^{1} \mathrm{H}$ and ${ }^{13} \mathrm{C}$ NMR spectra were recorded on a Varian Mercury 300 spectrometer (at $300 \mathrm{MHz}$ and $75 \mathrm{MHz}$ respectively) and are reported relative to $\mathrm{Me}_{4} \mathrm{Si}(\delta 0.0)$. Data for ${ }^{1} \mathrm{H}$ NMR spectra are reported as follows: chemical shift ( $\left.\delta \mathrm{ppm}\right)$, multiplicity, coupling constant $(\mathrm{Hz})$ and integration. Data for ${ }^{13} \mathrm{C}$ NMR spectra are reported in terms of chemical shift. Quantitative analysis was carried out by Desert Analytics Laboratory, Tuscon, AZ. X-ray crystallographic structures were obtained by Mr. Larry M. Henling and Dr. Mike W. Day of the California Institute of Technology Beckman Institute X-Ray Crystallography Laboratory.

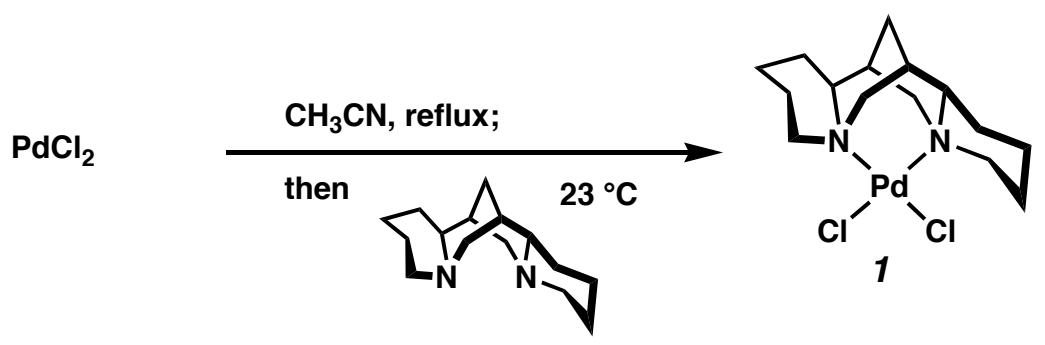

(sp)PdCl 1 1. $\mathrm{PdCl}_{2}\left(1.5 \mathrm{~g}, 8.46 \mathrm{mmol}, 1.0\right.$ equiv) was suspended in $\mathrm{CH}_{3} \mathrm{CN}$ (40 mL) and refluxed under $\mathrm{N}_{2}$ until formation of $\left(\mathrm{CH}_{3} \mathrm{CN}\right)_{2} \mathrm{PdCl}_{2}$ was complete, as indicated by the change in color of the suspension form dark purple to yellow-orange. The mixture was allowed to cool to 23 ${ }^{\circ} \mathrm{C}$ at which time (-)-sparteine $(1.94 \mathrm{~mL}, 8.46 \mathrm{mmol}, 1.0$ equiv) was added. Upon stirring of the dark orange-red solution for $1 \mathrm{~h}$ under $\mathrm{N}_{2}$, an orange precipitate formed which was isolated via filtration in air. Trituration of the orange solid from $\mathrm{CHCl}_{3}$ with $\mathrm{Et}_{2} \mathrm{O}$ resulted in $\mathbf{1}$ as a pale orange powder (2.89 g, $7.02 \mathrm{mmol}, 83 \%$ yield) that was identical by NMR to previously published reports. ${ }^{2}$ A single crystal suitable for X-ray analysis was grown by slow evaporation from $\mathrm{CDCl}_{3}$.
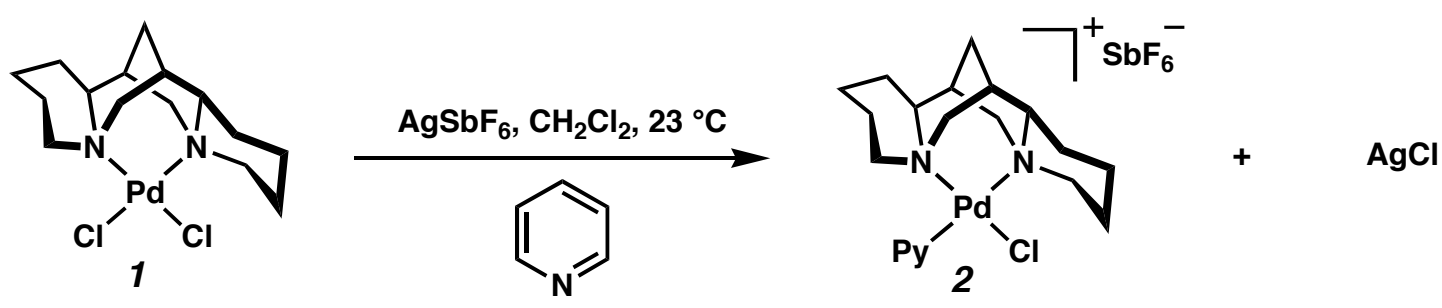

[(sparteine)Pd(pyridine) $\mathbf{C l}^{+} \mathbf{S b F}_{6}-2$ 2. A Schlenk flask was charged with $\mathrm{AgSbF}_{6}(163 \mathrm{mg}$, $0.475 \mathrm{mmol}, 1.0$ equiv) and $(\mathrm{sp}) \mathrm{PdCl}_{2}(\mathbf{1})(196 \mathrm{mg}, 0.475 \mathrm{mmol}, 1.0$ equiv). Addition of pyridine

2 Jensen, D. R.; Pugsley, J. S.; Sigman, M. S. J. Am. Chem. Soc. 2001, 123, 7475. 
( $38 \mu \mathrm{L}, 0.475 \mathrm{mmol}, 1.0$ equiv) via syringe followed immediately by $\mathrm{CH}_{2} \mathrm{Cl}_{2}$ (10 mL,) resulted in nearly instantaneous formation of an orange-yellow solution and pale precipitate. After stirring for $30 \mathrm{~min}$, silver chloride was removed by filtration through Celite in air. Concentration of the filtrate under vacuum yielded 2 as a yellow-orange solid ( $276 \mathrm{mg}, 0.399 \mathrm{mmol}, 84 \%$ yield) of $80 \%$ purity. Crystals suitable for x-ray diffraction were grown from acetone layered with pentane. The ${ }^{1} \mathrm{HNMR}$ spectrum of the crystalline material was identical to that of the major compound in the crude product. ${ }^{1} \mathrm{H}$ NMR $\left(300 \mathrm{MHz}\right.$, acetone- $\left.d_{6}\right) \delta 9.16(\mathrm{~d}, J=4.9 \mathrm{~Hz}, 1 \mathrm{H}), 8.89(\mathrm{~d}, J=5.5 \mathrm{~Hz}, 1 \mathrm{H})$, 8.06 (app.tt, $J=7.7,1.7 \mathrm{~Hz}, 1 \mathrm{H}), 7.67-7.59$ (comp m, 2H), 4.69 (dd, $J=12.1,3.3 \mathrm{~Hz}, 1 \mathrm{H}), 4.00$ (dt, $J=13.2,2.2 \mathrm{~Hz}, 1 \mathrm{H}), 3.77(\mathrm{dt}, J=11.5,1.7 \mathrm{~Hz}, 1 \mathrm{H}), 3.24-2.82$ (comp m, 2H), 2.81-2.71 (comp m, $2 \mathrm{H}), 2.48(\mathrm{~m} \mathrm{1H}), 2.33-1.48(\mathrm{comp} \mathrm{m}, 17 \mathrm{H}), 1.10(\mathrm{~m}, 1 \mathrm{H}) ;{ }^{13} \mathrm{C}$ NMR $\left(75 \mathrm{MHz}\right.$, acetone- $\left.d_{6}\right) \delta$ 153.7, 152.7, 140.3, 127.7, 126.9, 69.9, 66.6, 66.0, 64.8, 63.7, 49.1, 35.4, 35.1, 31.3, 27.2, 27.0, 26.2, 24.8, 24.1, 21.1. Anal. Calcd for $\mathrm{C}_{20} \mathrm{H}_{31} \mathrm{ClF}_{6} \mathrm{~N}_{3} \mathrm{PdSb}$ : C, 34.76; H, 4.52; N, 6.08. Found: $\mathrm{C}$, 34.90; H, 4.64; N, 5.79. mp 137-130 ${ }^{\circ} \mathrm{C}$ dec.

Attempted thermolysis of [(sparteine)Pd(pyridine)Cl] ${ }^{+} \mathbf{S b F}_{6}^{-}(\mathbf{2}) .2$ (15.1 $\left.\mathrm{mg}, 0.022 \mathrm{mmol}\right)$ was weighed into a sealable NMR tube and dissolved in dichloroethane- $d_{4}(0.740 \mathrm{~mL})$. A ${ }^{1} \mathrm{HNMR}$ spectrum was acquired. After the tube was heated to $80{ }^{\circ} \mathrm{C}$ for $4 \mathrm{~h}$ in an oil bath, an ${ }^{1}$ HNMR spectrum was again acquired. No change was observed.

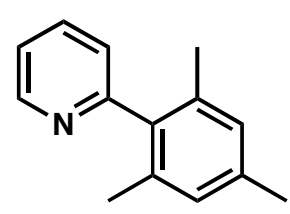

S01

2-Mesitylpyridine S01. S01 was prepared by the modified procedure of Hermann, et al. ${ }^{3}$ A Schlenk tube was charged with nickel(II) acetoacetonate (103 mg, $0.40 \mathrm{mmol}, 0.05 \mathrm{~mol} \%$ ), 1,3bis(2,4,6-trimethylphenyl)-imidazolium chloride (136 mg, $0.40 \mathrm{mmol}, 0.05 \mathrm{~mol} \%)$ and 2chloropyridine $(757 \mu \mathrm{L}, 8.0 \mathrm{mmol}, 1.0$ equiv) under argon. After addition of THF $(8.0 \mathrm{~mL})$, the pale green mixture was stirred for $15 \mathrm{~min}$. Mesityl magnesium bromide $(1.83 \mathrm{~mL}, 2.0 \mathrm{M}$ in THF, $12.0 \mathrm{mmol}, 1.5$ equiv) was transferred via cannula to the mixture, which immediately became dark brown. After stirring for $45 \mathrm{~m}$, methanol $(5 \mathrm{~mL})$ was added and the mixture filtered over Celite and concentrated in vacuo. Flash column chromatography on silica gel (9:1 Hexanes/EtOAc eluent) afforded a pale pink oil (1.42 g, $7.2 \mathrm{mmol}, 90 \%$ yield), identical by ${ }^{1} \mathrm{H}$ NMR to that reported.
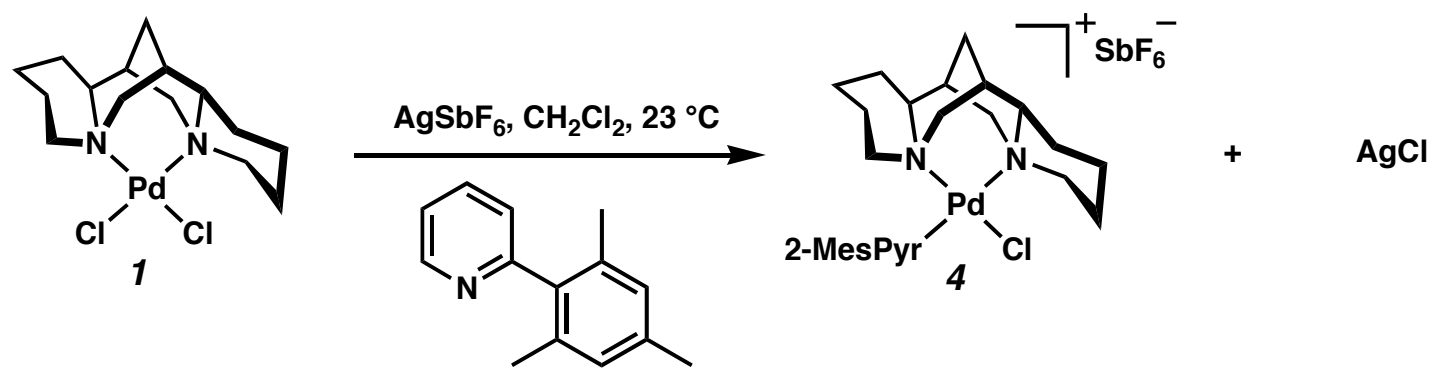

[(sparteine)Pd(2-mesitylpyridine) $\mathbf{C l}]^{+} \mathrm{SbF}_{6}-4.4$ was prepared according to the method described for 2 which led to a yellow-orange solid (361 mg, $0.446 \mathrm{mmol}, 94 \%$ yield) of $83 \%$ purity. Crystals suitable for x-ray diffraction were grown by slow diffusion of pentane into an

${ }^{3}$ Boehm, V. P. W.; Weskamp, T.; Gstoettmayr, C. W. K.; Hermann, W. A. Angew. Chem. Int. Ed. 2000, 39, 1602. 
acetone solution of 4 . The ${ }^{1} \mathrm{HNMR}$ spectrum of the crystalline material was identical to that of the major compound in the crude product. ${ }^{1} \mathrm{H}$ NMR $\left(300 \mathrm{MHz}, \mathrm{CD}_{2} \mathrm{Cl}_{2}\right) \delta 8.87(\mathrm{~d}, J=5.5 \mathrm{~Hz}, 1 \mathrm{H})$, $7.94(\mathrm{td}, J=7.7,1.6 \mathrm{~Hz}, 1 \mathrm{H}), 7.52(\mathrm{td}, J=6.0,1.6 \mathrm{~Hz}, 1 \mathrm{H}), 7.34(\mathrm{~d}, 7.7 \mathrm{~Hz}, 1 \mathrm{H}), 7.20(\mathrm{~s}, 1 \mathrm{H}), 7.18$ $(\mathrm{s}, 1 \mathrm{H}), 4.41(\mathrm{~d}, J=11.0 \mathrm{~Hz}, 1 \mathrm{H}), 3.79(\mathrm{~d}, J=12.1 \mathrm{~Hz}, 1 \mathrm{H}), 3.61(\mathrm{dt}, J=12.6,2.2 \mathrm{~Hz}, 1 \mathrm{H}), 2.78-$ 1.13 (comp m, 23H), 2.42 (s, 3H), $2.21(\mathrm{~s}, 3 \mathrm{H}), 2.08(\mathrm{~s}, 3 \mathrm{H}) ;{ }^{13} \mathrm{C} \mathrm{NMR}\left(75 \mathrm{MHz}, \mathrm{CD}_{2} \mathrm{Cl}_{2}\right) \delta 162.1$, $154.9,141.2$, 139.9, 139.5, 135.5, 134.4, 130.3, 129.6, 129.4, 125.7, 70.1, 67.3, 65.3, 64.8, 64.0, 48.3, 34.8, 34.3, 28.9, 27.3, 27.0, 25.2, 24.6, 23.9, 22.2, 21.4, 21.3, 20.6. Anal. Calcd for $\mathrm{C}_{29} \mathrm{H}_{41} \mathrm{ClF}_{6} \mathrm{~N}_{3} \mathrm{PdSb}$ : C, 43.04; H, 5.11; N, 5.19. Found: C, 43.08; H, 4.99; N, 5.02. mp 140-145 ${ }^{\circ} \mathrm{C}$ dec.

Attempted thermolysis of $[(\text { sparteine }) \mathbf{P d}(2-\text {-mesitylpyridine }) \mathbf{C l}]^{+} \mathrm{SbF}_{\mathbf{6}}^{-}$(4). 4 (6.1 $\mathrm{mg}$, $0.0069 \mathrm{mmol})$ was weighed into a sealable NMR tube and dissolved in dichloroethane- $d_{4}(0.750$ $\mathrm{mL}$ ). A ${ }^{1} \mathrm{HNMR}$ spectrum was acquired. After the tube was heated to $80{ }^{\circ} \mathrm{C}$ for $2 \mathrm{~h}$ in an oil bath, a ${ }^{1}$ HNMR spectrum was again acquired. No change was observed.
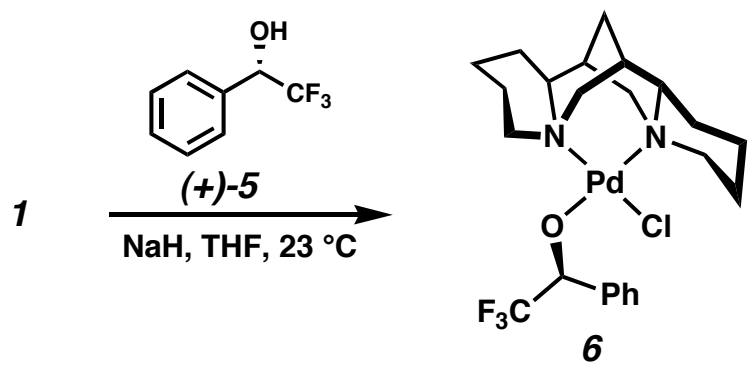

(sparteine)Pd(OCH $\left.\left(\mathrm{CF}_{3}\right) \mathbf{C}_{6} \mathbf{H}_{5}\right) \mathbf{C l}$ 6. (+)-S- $\alpha$-(trifluoromethyl)benzyl alcohol $(97 \mu \mathrm{L}, 0.713$ mmol, 1.0 equiv) was treated with an excess of sodium hydride (60\% dispersion in mineral oil, 57 $\mathrm{mg}, 1.43 \mathrm{mmol}, 2.0$ equiv) in THF (5 mL) under argon. After bubbling had ceased, the alkoxide was transferred to a stirring suspension of (sparteine) $\mathrm{PdCl}_{2}(\mathbf{1})(294 \mathrm{mg}, 0.713 \mathrm{mmol}, 1.0 \mathrm{equiv})$ in THF $(19 \mathrm{~mL})$ under argon at $23{ }^{\circ} \mathrm{C}$. The yellow-orange suspension gradually became an orange solution with very fine white precipitate. After stirring for $30 \mathrm{~min}$, the orange solution was filtered away from the sodium chloride and the solvents removed under vacuum to afford an orange solid (336 mg, $0.61 \mathrm{mmol}, 84 \%$ yield) of $74 \%$ purity. 6 was obtained after recrystallization from $\mathrm{CH}_{2} \mathrm{Cl}_{2}$ layered with hexane at $-20{ }^{\circ} \mathrm{C}$ in a glove box as an unstable dark orange solid $(215 \mathrm{mg} 0.39 \mathrm{mmol}$, $64 \%$ yield from crude material). The ${ }^{1} \mathrm{HNMR}$ spectrum of the crystalline material corresponded exactly to that of the major species in the crude product. A single crystal suitable for x-ray diffraction was grown from $\mathrm{CH}_{2} \mathrm{Cl}_{2}$ layered with hexane at $-20{ }^{\circ} \mathrm{C} .{ }^{1} \mathrm{H}$ NMR $\left(300 \mathrm{MHz}, \mathrm{CD}_{2} \mathrm{Cl}_{2}\right) \delta$ $7.57(\mathrm{~d}, J=7.2 \mathrm{~Hz}, 2 \mathrm{H}), 7.44-7.34(\operatorname{comp~m}, 3 \mathrm{H}), 5.11(\mathrm{q}, J=8.0 \mathrm{~Hz}, 1 \mathrm{H}), 4.53(\mathrm{~d}, J=11.7 \mathrm{~Hz}$, 1H), 3.70-3.52 (comp m, 3H), 2.85-2.72 (comp m, 2H), 2.48-1.15 (comp m, 20H); ${ }^{13} \mathrm{C}$ NMR (75 $\mathrm{MHz}, \mathrm{CD}_{2} \mathrm{Cl}_{2}$ ) d 129.9, 128.9, 128.8, 128.54, 128.47, 128.2, 78.5 (d, $\left.J=27.7\right), 69.9,65.7,65.6$, $64.3,57.4,49.2,35.4,34.9,29.8,28.0,27.4,25.3,24.7,24.2,20.5$.
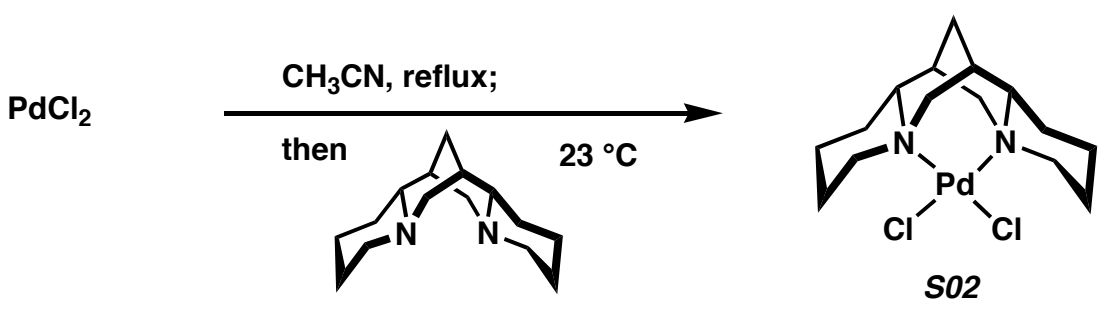
( $\alpha$-isosparteine)PdCl ${ }_{2}$ S02. (-)- $\alpha$-isosparteine was prepared by the method of Leonard. ${ }^{4}$ $\left(\mathrm{CH}_{3} \mathrm{CN}\right)_{2} \mathrm{PdCl}_{2}(73 \mathrm{mg}, 0.28 \mathrm{mmol}, 1.0$ equiv) and (-)- $\alpha$-isosparteine $(66 \mathrm{mg}, 0.28 \mathrm{mmol}, 1.0$ equiv) were dissolved in $\mathrm{CH}_{3} \mathrm{CN}(5 \mathrm{~mL})$ and allowed to stir at $23{ }^{\circ} \mathrm{C}$ under argon for $1 \mathrm{~h}$. The dark orange solution was filtered through Celite and concentrated in vacuo to afford $\mathbf{S 0 2}$ as a rustcolored microcrystalline solid (84 mg, $0.20 \mathrm{mmol}, 72 \%$ yield). A single crystal suitable for x-ray diffraction was grown by slow evaporation from $\mathrm{CH}_{2} \mathrm{Cl}_{2}$. ${ }^{1} \mathrm{H}$ NMR $\left(300 \mathrm{MHz}, \mathrm{CD}_{2} \mathrm{Cl}_{2}\right) \delta 3.95$ $(\mathrm{qd}, J=12.4,3.9 \mathrm{~Hz}, 2 \mathrm{H}), 3.72-3.66(\mathrm{~m}, 2 \mathrm{H}), 3.51(\mathrm{~d}, J=12.4 \mathrm{~Hz}, 2 \mathrm{H}), 2.98-2.84(\mathrm{~m}, 2 \mathrm{H}), 2.24-$ $2.19(\mathrm{~m}, 2 \mathrm{H}), 2.15-2.10(\mathrm{~m}, 2 \mathrm{H}) 1.94-1.79(\mathrm{comp} \mathrm{m}, 10 \mathrm{H}), 1.65-1.51$ (comp m, $4 \mathrm{H}) ;{ }^{13} \mathrm{C} \mathrm{NMR}$ $\left(75 \mathrm{MHz}, \mathrm{CD}_{2} \mathrm{Cl}_{2}\right) \delta 72.15,64.6,60.7,35.8,35.5,30.9,25.5,25.0$. Anal. Calcd for $\mathrm{C}_{15} \mathrm{H}_{26} \mathrm{Cl}_{2} \mathrm{~N}_{2} \mathrm{Pd}: \mathrm{C}, 43.76 ; \mathrm{H}, 6.37 ; \mathrm{N}, 6.80$. Found: $\mathrm{C}$, 43.82; H, 6.36; N, 6.68. mp 180-182 ${ }^{\circ} \mathrm{C}$.

Oxidative Kinetic Resolution of 1-phenylethanol with S02 and 1. A thick-walled oven-dried $10 \mathrm{~mL}(1 \mathrm{~cm}$ OD) tube equipped with magnetic stir bar was charged with powdered molecular sieves (MS3 A, $150 \mathrm{mg}, 500 \mathrm{mg} / \mathrm{mmol}), \mathbf{S 0 2}$ or 1 (6.2 $\mathrm{mg}, 0.015 \mathrm{mmol}, 0.05$ equiv), and tridecane $(29.3 \mu \mathrm{L}, 0.12 \mathrm{mmol}, 0.40$ equiv) as internal standard, followed by toluene $(3.0 \mathrm{~mL}), 1$ phenylethanol (36 $\mu \mathrm{L}, 0.30 \mathrm{mmol}, 1$ equiv), and (-)- $\alpha$-isosparteine or sparteine $(10.5 \mathrm{mg}, 0.045$ mmol, 0.15 equiv). The tube was evacuated and back-filled with $\mathrm{O}_{2}\left(3 \mathrm{x}\right.$, balloon), heated to $80{ }^{\circ} \mathrm{C}$, and allowed to stir under $\mathrm{O}_{2}$ (1 atm, balloon). To monitor the reaction, aliquots $(200 \mu \mathrm{L})$ were removed and passed through a pipette plug of silica gel using $\mathrm{Et}_{2} \mathrm{O}$ as eluent. Conversion was analyzed by GC; the sample was then concentrated in vacuo and \%ee analyzed by chiral HPLC as previously reported ${ }^{5}$ (see Table S01).

Table S01. Oxidative Kinetic Resolution with S02 and 1 using (-)-sparteine and (-)- $\alpha$ isosparteine as the exogenous base.

\begin{tabular}{|c|c|c|c|c|c|c|}
\hline entry & substrate & catalyst & time & $\%$ conversion & \%ee & $\mathbf{s}^{c}$ \\
\hline $1^{a}$ & & ( $\alpha$-isosparteine) $\mathrm{PdCl}_{2}$ & $72 \mathrm{~h}$ & 33.6 & 28.6 & 4.7 \\
\hline $2^{b}$ & & $(\mathrm{sp}) \mathrm{PdCl}_{2}$ & $24 \mathrm{~h}$ & 58.1 & 93.2 & 17.3 \\
\hline
\end{tabular}

${ }^{\mathrm{a}}$ Data represent an average of two runs. ${ }^{\mathrm{b}}$ Data represent an average of three runs. ${ }^{\mathrm{c}}$ The selectivity factor, $s$, was determined by the following equation: $s=k_{\mathrm{rel}}=\ln [(1-\mathrm{C})(1-\mathrm{ee})] / \ln [(1-\mathrm{C})(1+\mathrm{ee})]$ where $\mathrm{C}$ is conversion and ee is enantiomeric excess.

Oxidative Kinetic Resolution of 1-phenylethanol with $\mathrm{SO2}$ and 1 with $\mathrm{Cs}_{2} \mathrm{CO}_{3}$ as the Sole Exogenous Base. In order to test whether the difference in $s$ between S02 and 1 in the oxidative kinetic resolution (see table S01) was due to a difference in the activity of the free alkaloids as bases, ${ }^{6}$ the resolution was carried out using only $\mathrm{Cs}_{2} \mathrm{CO}_{3}$ as the base under non-optimized

4 (a) Leonard, N. J.; Beyler, R. E. J. Am. Chem. Soc. 1948, 70, 2298. (b) Leonard, N. J.; Beyler, R. E. J. Am. Chem. Soc. 1950, 72, 1316.

5 (a) Ferreira, E. M.; Stoltz, B. M. J. Am. Chem. Soc. 2001, 123, 7725. (b) Bagdanoff, J. T.; Stoltz, B. M. Org. Lett. 2003, 5, 835.

${ }^{6}$ We thank a reviewer for raising this issue. 
conditions. A thick-walled oven-dried $10 \mathrm{~mL}(1 \mathrm{~cm}$ OD) tube equipped with magnetic stir bar was charged with powdered molecular sieves (MS3 ̊, $150 \mathrm{mg}, 500 \mathrm{mg} / \mathrm{mmol}), \mathbf{S 0 2}$ or 1 (6.2 mg, 0.015 mmol, 0.05 equiv), and tridecane $(29.3 \mu \mathrm{L}, 0.12 \mathrm{mmol}, 0.40$ equiv) as internal standard, followed by toluene $(3.0 \mathrm{~mL}), 1$-phenylethanol $(36 \mu \mathrm{L}, 0.30 \mathrm{mmol}, 1$ equiv), and finely ground anhydrous $\mathrm{Cs}_{2} \mathrm{CO}_{3}$ (98 mg, $0.300 \mathrm{mmol}, 1$ equiv). The tube was evacuated and back-filled with $\mathrm{O}_{2}(3 \mathrm{x}$, balloon), heated to $80^{\circ} \mathrm{C}$, and allowed to stir under $\mathrm{O}_{2}$ ( $1 \mathrm{~atm}$, balloon). To monitor the reaction, aliquots $(100 \mu \mathrm{L})$ were removed and passed through a pipette plug of silica gel using $\mathrm{Et}_{2} \mathrm{O}$ as eluent. Conversion was analyzed by GC; the sample was then concentrated in vacuo and \%ee analyzed by chiral HPLC as previously reported ${ }^{5}$ (see Table S02).

Table S02. Oxidative kinetic resolution with $\mathbf{S 0 2}$ and 1 using $\mathrm{Cs}_{2} \mathrm{CO}_{3}$ as the sole exogenous base.

\begin{tabular}{|c|c|c|c|c|c|c|}
\hline entry & substrate & catalyst & time & $\%$ conversion & \%ee & $\mathbf{s}^{\mathrm{b}}$ \\
\hline $1^{a}$ & & ( $\alpha$-isosparteine) $\mathrm{PdCl}_{2}$ & $12 \mathrm{~h}$ & 17.3 & 4.96 & 1.7 \\
\hline $2^{a}$ & & $(\mathrm{sp}) \mathrm{PdCl}_{2}$ & $12 \mathrm{~h}$ & 36.2 & 35.2 & 6.0 \\
\hline
\end{tabular}

${ }^{\mathrm{a}}$ Data represent an average of two runs. ${ }^{\mathrm{b}}$ The selectivity factor, $s$, was determined by the following equation: $s=k_{\mathrm{rel}}=\ln [(1-$ $\mathrm{C})(1-\mathrm{ee})] / \ln [(1-\mathrm{C})(1+\mathrm{ee})]$ where $\mathrm{C}$ is conversion and ee is enantiomeric excess.

Conversion of 6 to 2,2,2-trifluoroacetophenone. 6 (18.8 $\mathrm{mg}, 0.034 \mathrm{mmol}, 1.0$ equiv) and bis(trimethylsilyl)benzene ( $4.4 \mathrm{mg}, 0.021 \mathrm{mmol}, 0.59$ equiv) as internal standard were dissolved in $\mathrm{CD}_{2} \mathrm{Cl}_{2}(700 \mu \mathrm{L})$ in an NMR tube in the glove box. A ${ }^{1} \mathrm{HNMR}$ spectrum was acquired and the integration of resonances corresponding to the methine proton of $\mathbf{6}$ and the methyl resonance of bis(trimethylsilyl)benzene compared. The tube was taken into the glove box, and $\mathrm{AgSbF}_{6}(17.5$ $\mathrm{mg}, 0.051 \mathrm{mmol}, 1.5$ equiv) was added to the orange solution upon which a greenish-black suspension was produced immediately. A ${ }^{1} \mathrm{H}$ NMR spectrum was acquired which showed complete disappearance of resonances corresponding to 6 and the appearance of resonances corresponding to 2,2,2-trifluoroacetophenone (92\% yield based on integration of the ortho-aryl ${ }^{1} \mathrm{H}$ resonance of 2,2,2-trifluoroacetophenone and the methyl resonance of bis(trimethylsilyl)benzene and comparison with the first spectrum). 
Figure S11. Tabulation of palladium alkoxide structures possessing $\beta$-hydrogens reported in the Cambridge Structural Database. ${ }^{7}$

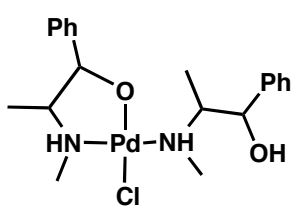

S03<smiles></smiles>

S07<smiles></smiles><smiles>C1=CC2=C3C=CC=CN3[P+]3(OC4COCC4O3)N2C=C1</smiles>

S04<smiles>OCC1OC2O[Te]3(NCCN3)OC2C2O[Pb]3(NCCN3)OC12</smiles>

S08<smiles>C[C@H](O[Pb]1(C)N(C)CCN1C)C(F)(F)F</smiles>

S12

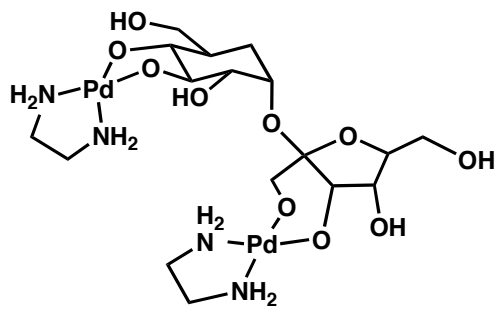

S15

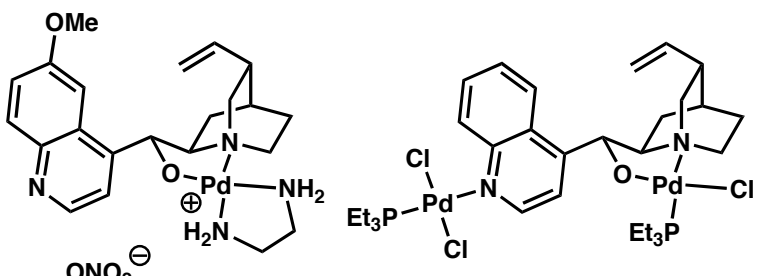

S05

S06<smiles>N[Pb]1(N)OCC(C2CO[Pb](N)(N)O2)O1</smiles>

So9<smiles>C1CN[Pb]2(N1)OC1COCC1O2</smiles>

513<smiles>OC1C2OC3COC(O3)C(O2)N1P1NCCN1</smiles>

S14

${ }^{7}$ S03: Bouquillon, S.; du Moullinet d'Hardemare, A.; Averbuch-Pouchot, M.-T.; Henin, F.; Muzart, J.; Durif, M. Acta Crystallogr., Sect. C: Cryst. Struct. Commun. 1999, 55, 2028. S04: Achternbosch, M.; Klufers, P. Acta Crystallogr., Sect. C: Cryst. Struct. Commun. 1994, 50, 175. S05, S06: Hubel, R.; Polborn, K.; Beck, W. Eur. J. Inorg. Chem. 1999, 471. S07: Kapteijn, G. M.; Grove, D. M.; van Koten, G.; Smeets, W. J. J.; Spek, A. L. Inorg. Chim. Acta 1993, 207, 131. S08: Klufers, P.; Kunte, T. Angew. Chem., Int. Ed. 2001, 40, 4210. S09: Kastele, X.; Klufers, P.; Kunte, T. Z. Anorg. Allg. Chem. 2001, 627, 2042. S10, S11: Kapteijn, G. M.; Baesjou, P.; Alsters, P. L.; Grove, D. M.; Smeets, W. J. J.; Kooijman, H.; Spek, A. L.; van Koten, G. Chem. Ber. 1997, 130, 35. S12: Kapteijn, G. M.; Dervisi, A.; Grove, D. M.; Kooijman, H.; Lakin, M. T.; Spek, A. L.; van Koten, G. J. Am. Chem. Soc. 1995, 117, 10939. S13, S14, S15: Ahlrichs, R.; Ballauff, M.; Eichkorn, K.; Hanemann, O.; Kettenbach, G.; Klufers, P. Chem.-Eur. J. 1998, 4, 835. S15: Klufers, P.; Kunte, T. Eur. J. Inorg. Chem. 2002, 1285. 


\section{MOLECULAR STTRUCTURES AND CRYSTALLOGRAPHIC DATA FOR 1, 2, 4, 6 AND S02}

Figure S12. (sparteine) $\mathrm{PdCl}_{2}(\mathbf{1})$ shown with $50 \%$ probability ellipsoids. Crystallographic data have been deposited at the CCDC, 12 Union Road, Cambridge CB2 1EZ, UK and copies can be obtained on request, free of charge, by quoting the publication citation and the deposition number 203513.

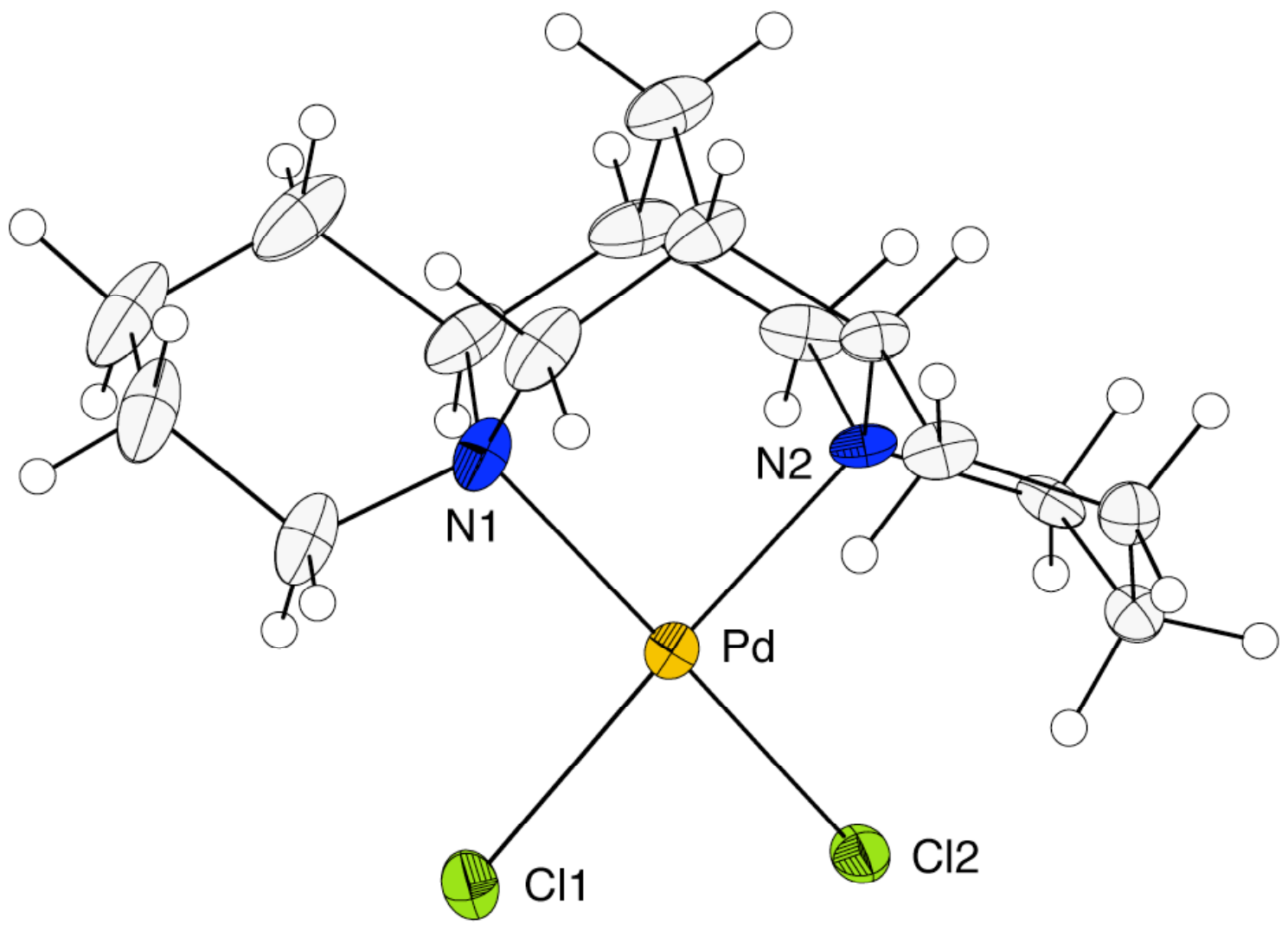

Table S03. Selected bond lengths $[\AA ̊]$ and angles for 1 (CCDC 203513)

\begin{tabular}{llll}
\hline & $2.096(3)$ & $\mathrm{N}(2)-\mathrm{Pd}-\mathrm{N}(1)$ & \\
$\mathrm{Pd}-\mathrm{N}(2)$ & $2.127(2)$ & $\mathrm{N}(2)-\mathrm{Pd}-\mathrm{Cl}(2)$ & $87.51(10)$ \\
$\mathrm{Pd}-\mathrm{N}(1)$ & $2.3150(8)$ & $\mathrm{N}(1)-\mathrm{Pd}-\mathrm{Cl}(2)$ & $93.44(7)$ \\
$\mathrm{Pd}-\mathrm{Cl}(2)$ & $2.3161(9)$ & $\mathrm{N}(2)-\mathrm{Pd}-\mathrm{Cl}(1)$ & $170.06(8)$ \\
$\mathrm{Pd}-\mathrm{Cl}(1)$ & & $\mathrm{N}(1)-\mathrm{Pd}-\mathrm{Cl}(1)$ & $176.24(7)$ \\
& & $\mathrm{Cl}(2)-\mathrm{Pd}-\mathrm{Cl}(1)$ & $95.65(8)$ \\
& & & $83.09(3)$ \\
\hline
\end{tabular}


Table S04. Crystal data and structure refinement for 1 (CCDC 203513).

Empirical formula

Formula weight

Crystallization Solvent

Crystal Habit

Crystal size

Crystal color

Preliminary Photos

Type of diffractometer

Wavelength

Data Collection Temperature

$\theta$ range for 17268 reflections used

in lattice determination

Unit cell dimensions

Volume

Z

Crystal system

Space group

Density (calculated)

$\mathrm{F}(000)$

$\theta$ range for data collection

Completeness to $\theta=28.44^{\circ}$

Index ranges

Data collection scan type

Reflections collected

Independent reflections

Absorption coefficient

Absorption correction

Max. and min. transmission

Structure solution program

Primary solution method

Secondary solution method
$\mathrm{C}_{15} \mathrm{H}_{26} \mathrm{Cl}_{2} \mathrm{~N}_{2} \mathrm{Pd} \cdot 2 \mathrm{CHCl}_{3}$

650.41

Chloroform

Blade

$0.33 \times 0.15 \times 0.06 \mathrm{~mm}^{3}$

Orange

\section{Data Collection}

Rotation

Bruker SMART 1000

$0.71073 \AA$ MoK $\alpha$

98(2) K

2.17 to $28.42^{\circ}$

$\mathrm{a}=10.5805(7) \AA$

$\mathrm{b}=12.4401(8) \AA$

$c=18.6906(12) \AA$

2460.1(3) $\AA^{3}$

4

Orthorhombic

$\mathrm{P} 2{ }_{1} 2_{1} 2_{1}$

$1.756 \mathrm{Mg} / \mathrm{m}^{3}$

1304

1.97 to $28.44^{\circ}$

$96.7 \%$

$-13 \leq \mathrm{h} \leq 14,-16 \leq \mathrm{k} \leq 16,-24 \leq 1 \leq 24$

$\omega$ scans at $5 \phi$ settings

43840

$5883\left[\mathrm{R}_{\mathrm{int}}=0.0794\right]$

$1.632 \mathrm{~mm}^{-1}$

None

0.9084 and 0.6150

\section{Structure solution and Refinement}

SHELXS-97 (Sheldrick, 1990)

Patterson method

Difference Fourier map 
Table S04 continued. Crystal data and structure refinement for $\mathbf{1}$ (CCDC 203513).

Hydrogen placement

Structure refinement program

Refinement method

Data / restraints / parameters

Treatment of hydrogen atoms

Goodness-of-fit on $\mathrm{F}^{2}$

Final R indices [I $>2 \sigma(\mathrm{I}), 22793$ reflections]

$\mathrm{R}$ indices (all data)

Type of weighting scheme used

Weighting scheme used

Max shift/error

Average shift/error

Absolute structure parameter

Largest diff. peak and hole
Difference Fourier map

SHELXL-97 (Sheldrick, 1997)

Full matrix least-squares on $\mathrm{F}^{2}$

5883 / 24 / 329

Riding

1.367

$\mathrm{R} 1=0.0332, w \mathrm{R} 2=0.0526$

$\mathrm{R} 1=0.0436 w \mathrm{R} 2=0.0538$

Sigma

$w=1 / \sigma^{2}\left(\mathrm{Fo}^{2}\right)$

0.002

0.000

$-0.04(2)$

0.984 and -0.639 e. $\AA^{-3}$

\section{Special Refinement Details}

The crystals contain chloroform as a solvent of co-crystallization. Each asymmetric unit contains two molecules of disordered chloroform. The disorder was successfully modeled and all solvent atoms were refined anisotropically. However, the 1,2 and 1,3 distances within the solvents were restrained to be similar and each distance was assigned a free variable so as to not place artificial values in the geometry. All hydrogen atoms were constrained to ride on the corresponding carbon.

Refinement of $\mathrm{F}^{2}$ against ALL reflections. The weighted R-factor $(w \mathrm{R})$ and goodness of fit $(\mathrm{S})$ are based on $\mathrm{F}^{2}$, conventional R-factors $(\mathrm{R})$ are based on $\mathrm{F}$, with $\mathrm{F}$ set to zero for negative $\mathrm{F}^{2}$. The threshold expression of $\mathrm{F}^{2}>$ $2 \sigma\left(\mathrm{F}^{2}\right)$ is used only for calculating R-factors $(\mathrm{gt})$ etc. and is not relevant to the choice of reflections for refinement. $\mathrm{R}$-factors based on $\mathrm{F}^{2}$ are statistically about twice as large as those based on $\mathrm{F}$, and R-factors based on ALL data will be even larger.

All esds (except the esd in the dihedral angle between two 1.s. planes) are estimated using the full covariance matrix. The cell esds are taken into account individually in the estimation of esds in distances, angles and torsion angles; correlations between esds in cell parameters are only used when they are defined by crystal symmetry. An approximate (isotropic) treatment of cell esds is used for estimating esds involving l.s. planes. 
Figure S13. [(sparteine)Pd(pyridine)Cl $]^{+} \mathrm{SbF}_{6}{ }^{-}$(2) shown with $50 \%$ probability ellipsoids. The anion has been omitted for clarity. Crystallographic data have been deposited at the CCDC, 12 Union Road, Cambridge CB2 1EZ, UK and copies can be obtained on request, free of charge, by quoting the publication citation and the deposition number 213927.

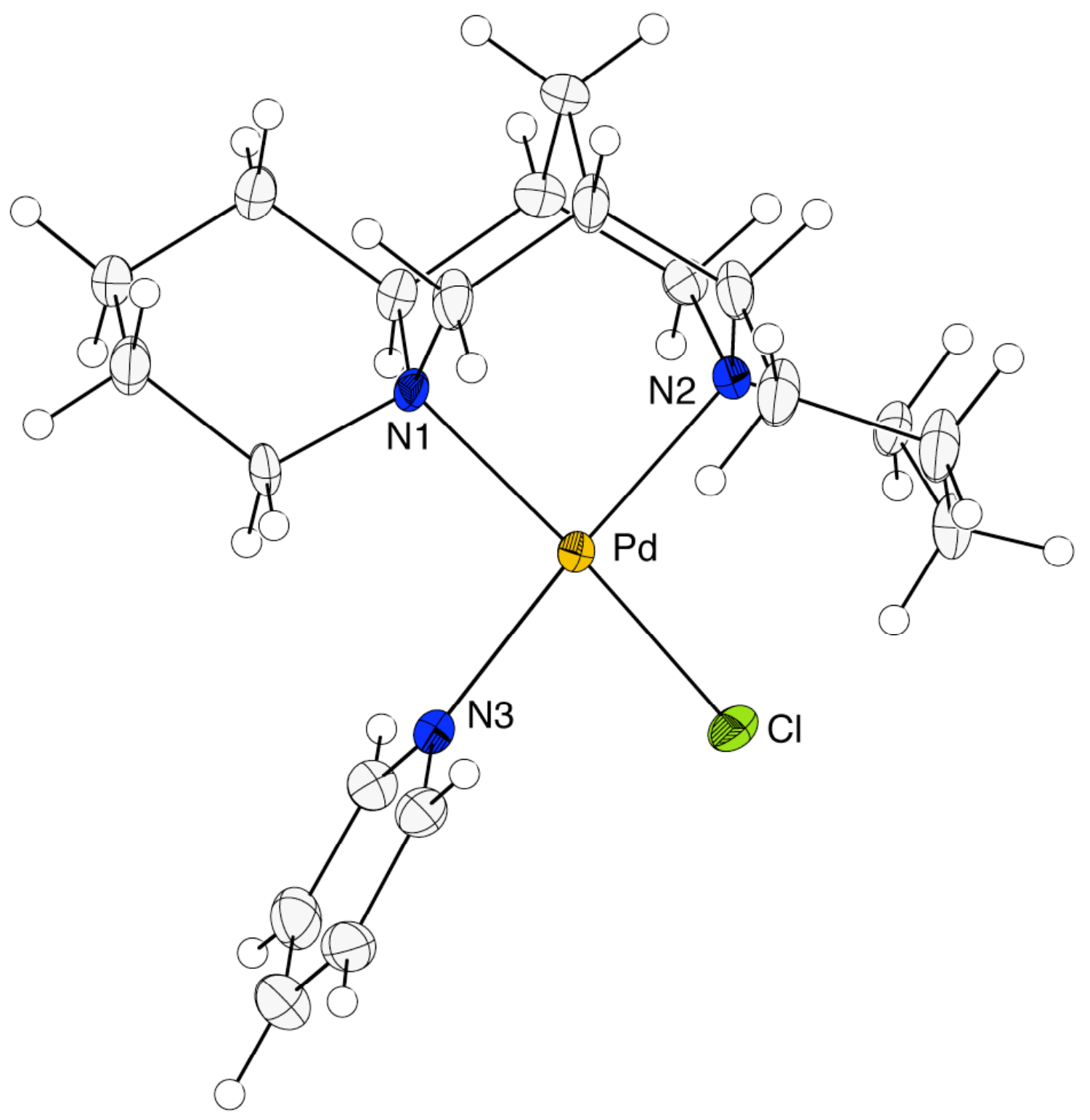

Table S05. Selected bond lengths $[\AA ̊]$ and angles for 2 (CCDC 213927).

\begin{tabular}{llll}
\hline & & & \\
Pd-N(3) & $2.046(3)$ & N(3)-Pd-N(2) & $176.64(10)$ \\
Pd-N(2) & $2.087(2)$ & N(3)-Pd-N(1) & $95.73(9)$ \\
Pd-N(1) & $2.122(2)$ & N(2)-Pd-N(1) & $87.39(9)$ \\
Pd-Cl & $2.3105(7)$ & N(3)-Pd-Cl & $81.52(7)$ \\
& & N(2)-Pd-Cl & $95.67(7)$ \\
& & N(1)-Pd-Cl & $168.52(7)$ \\
\hline
\end{tabular}


Table S06. Crystal data and structure refinement for 2 (CCDC 213927).

Empirical formula

Formula weight

Crystallization Solvent

Crystal Habit

Crystal size

Crystal color

Preliminary Photos

Type of diffractometer

Wavelength

Data Collection Temperature

$\theta$ range for 54240 reflections used in lattice determination

Unit cell dimensions

Volume

Z

Crystal system

Space group

Density (calculated)

$\mathrm{F}(000)$

Data collection program

$\theta$ range for data collection

Completeness to $\theta=40.92^{\circ}$

Index ranges

Data collection scan type

Data reduction program

Reflections collected

Independent reflections

Absorption coefficient

Absorption correction

Max. and min. transmission
$\left[\mathrm{C}_{20} \mathrm{H}_{31} \mathrm{ClN}_{3} \mathrm{Pd}\right]^{+}\left[\mathrm{SbF}_{6}\right]^{-}$

691.08

Acetone/pentane

Block

$0.23 \times 0.20 \times 0.19 \mathrm{~mm}^{3}$

Yellow

\section{Data Collection}

Rotation

Bruker SMART 1000

$0.71073 \AA$ MoK $\alpha$

100(2) K

2.19 to $39.64^{\circ}$

$\mathrm{a}=10.3598(2) \AA$

$\mathrm{b}=22.2422(3) \AA$

$\mathrm{c}=10.8117(2) \AA$

$\beta=104.3020(10)^{\circ}$

2414.07(7) $\AA^{3}$

4

Monoclinic

$\mathrm{P} 2{ }_{1}$

$1.901 \mathrm{Mg} / \mathrm{m}^{3}$

1360

Bruker SMART v5.054

1.83 to $40.92^{\circ}$

$97.6 \%$

$-18 \leq \mathrm{h} \leq 18,-40 \leq \mathrm{k} \leq 40,-19 \leq 1 \leq 19$

$\omega$ scans at $7 \phi$ and $22 \theta$ settings

Bruker SAINT v6.022

110239

$29947\left[\mathrm{R}_{\mathrm{int}}=0.0717\right]$

$2.034 \mathrm{~mm}^{-1}$

Calculated, NOT applied

0.6986 and 0.6520 
Table S06 continued. Crystal data and structure refinement for 2 (CCDC 213927).

Structure solution and Refinement

Structure solution program

Primary solution method

Secondary solution method

Hydrogen placement

Structure refinement program

Refinement method

Data / restraints / parameters

Treatment of hydrogen atoms

Goodness-of-fit on $\mathrm{F}^{2}$

Final $R$ indices [I $>2 \sigma(I), 22793$ reflections]

$\mathrm{R}$ indices (all data)

Type of weighting scheme used

Weighting scheme used

Max shift/error

Average shift/error

Absolute structure parameter

Largest diff. peak and hole
SHELXS-97 (Sheldrick, 1990)

Patterson method

Difference Fourier map

Geometric positions

SHELXL-97 (Sheldrick, 1997)

Full matrix least-squares on $\mathrm{F}^{2}$

29947 / 1 / 577

Constrained

1.664

$\mathrm{R} 1=0.0503, w \mathrm{R} 2=0.0842$

$\mathrm{R} 1=0.0709, w \mathrm{R} 2=0.0864$

Sigma

$w=1 / \sigma^{2}\left(\mathrm{Fo}^{2}\right)$

0.001

0.000

$-0.018(12)$

5.743 and -4.948 e. $\AA^{-3}$

\section{Special Refinement Details}

Refinement of $\mathrm{F}^{2}$ against ALL reflections. The weighted R-factor $(w \mathrm{R})$ and goodness of fit $(\mathrm{S})$ are based on $\mathrm{F}^{2}$, conventional R-factors $(\mathrm{R})$ are based on $\mathrm{F}$, with $\mathrm{F}$ set to zero for negative $\mathrm{F}^{2}$. The threshold expression of $\mathrm{F}^{2}>$ $2 \sigma\left(F^{2}\right)$ is used only for calculating R-factors (gt) etc. and is not relevant to the choice of reflections for refinement. $\mathrm{R}$-factors based on $\mathrm{F}^{2}$ are statistically about twice as large as those based on F, and R-factors based on ALL data will be even larger.

All esds (except the esd in the dihedral angle between two 1.s. planes) are estimated using the full covariance matrix. The cell esds are taken into account individually in the estimation of esds in distances, angles and torsion angles; correlations between esds in cell parameters are only used when they are defined by crystal symmetry. An approximate (isotropic) treatment of cell esds is used for estimating esds involving l.s. planes. 
Figure S14. [(sparteine)Pd(2-mesitylpyridine $) \mathrm{Cl}^{+} \mathrm{SbF}_{6}^{-}$(4) shown with $50 \%$ probability ellipsoids. The anion has been omitted for clarity. Crystallographic data have been deposited at the CCDC, 12 Union Road, Cambridge CB2 1EZ, UK and copies can be obtained on request, free of charge, by quoting the publication citation and the deposition number 215758 .

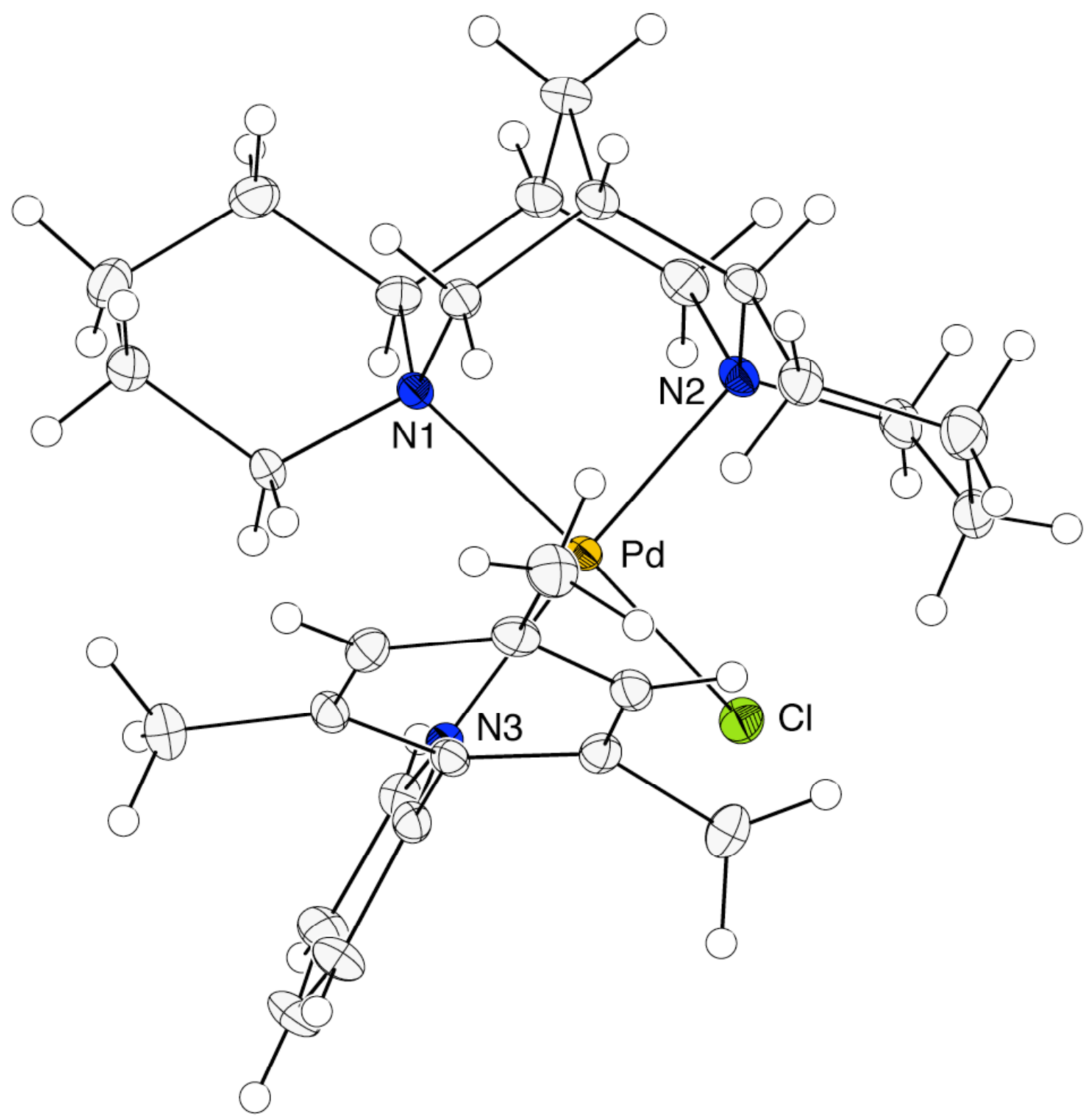

Table S07. Selected bond lengths $[\AA]$ and angles for 4 (CCDC 215758).

\begin{tabular}{llll}
\hline & & & \\
Pd-N(3) & $2.0809(13)$ & $\mathrm{N}(3)-\mathrm{Pd}-\mathrm{N}(2)$ & $175.42(5)$ \\
$\mathrm{Pd}-\mathrm{N}(2)$ & $2.0914(14)$ & $\mathrm{N}(3)-\mathrm{Pd}-\mathrm{N}(1)$ & $96.95(5)$ \\
$\mathrm{Pd}-\mathrm{N}(1)$ & $2.1326(14)$ & $\mathrm{N}(2)-\mathrm{Pd}-\mathrm{N}(1)$ & $87.48(9)$ \\
Pd-Cl & $2.3345(4)$ & $\mathrm{N}(3)-\mathrm{Pd}-\mathrm{Cl}$ & $82.53(4)$ \\
& & $\mathrm{N}(2)-\mathrm{Pd}-\mathrm{Cl}$ & $93.56(4)$ \\
& & $\mathrm{N}(1)-\mathrm{Pd}-\mathrm{Cl}$ & $163.51(4)$ \\
\hline
\end{tabular}


Table S08. Crystal data and structure refinement for 4 (CCDC 215758).

\begin{tabular}{|c|c|}
\hline Empirical formula & {$\left[\mathrm{C}_{29} \mathrm{H}_{41} \mathrm{~N}_{3} \mathrm{ClPd}\right]^{+}\left[\mathrm{SbF}_{6}\right]^{-}$} \\
\hline Formula weight & 809.25 \\
\hline Crystallization Solvent & Acetone/pentane \\
\hline Crystal Habit & Block \\
\hline Crystal size & $0.30 \times 0.30 \times 0.26 \mathrm{~mm}^{3}$ \\
\hline \multirow[t]{2}{*}{ Crystal color } & Clear \\
\hline & Data Collection \\
\hline Preliminary Photos & Rotation \\
\hline Type of diffractometer & Bruker SMART 1000 \\
\hline Wavelength & $0.71073 \AA ̊ \mathrm{MoK} \alpha$ \\
\hline Data Collection Temperature & $100(2) \mathrm{K}$ \\
\hline $\begin{array}{l}\theta \text { range for } 41762 \text { reflections used } \\
\text { in lattice determination }\end{array}$ & 2.27 to $40.10^{\circ}$ \\
\hline Unit cell dimensions & $\begin{array}{l}\mathrm{a}=12.3773(2) \AA \\
\mathrm{b}=13.1425(2) \AA \\
\mathrm{c}=18.7060(3) \AA\end{array}$ \\
\hline Volume & $3042.88(8) \AA^{3}$ \\
\hline $\mathrm{Z}$ & 4 \\
\hline Crystal system & Orthorhombic \\
\hline Space group & $\mathrm{P} 2{ }_{1} 2_{1} 2_{1}$ \\
\hline Density (calculated) & $1.766 \mathrm{Mg} / \mathrm{m}^{3}$ \\
\hline $\mathrm{F}(000)$ & 1616 \\
\hline Data collection program & Bruker SMART v5.054 \\
\hline$\theta$ range for data collection & 1.89 to $40.43^{\circ}$ \\
\hline Completeness to $\theta=40.43^{\circ}$ & $96.5 \%$ \\
\hline Index ranges & $-22 \leq \mathrm{h} \leq 22,-22 \leq \mathrm{k} \leq 23,-33 \leq 1 \leq 32$ \\
\hline Data collection scan type & $\omega$ scans at $3 \phi$ settings each for two $2 \theta$ settings \\
\hline Data reduction program & Bruker SAINT v6.022 \\
\hline Reflections collected & 77220 \\
\hline Independent reflections & $18496\left[\mathrm{R}_{\mathrm{int}}=0.0639\right]$ \\
\hline Absorption coefficient & $1.628 \mathrm{~mm}^{-1}$ \\
\hline Absorption correction & None \\
\hline Max. and min. transmission (predicted) & 0.6769 and 0.6409 \\
\hline
\end{tabular}


Table S08 continued. Crystal data and structure refinement for 4 (CCDC 215758).

\section{Structure solution and Refinement}

Structure solution program

Primary solution method

Secondary solution method

Hydrogen placement

Structure refinement program

Refinement method

Data / restraints / parameters

Treatment of hydrogen atoms

Goodness-of-fit on $\mathrm{F}^{2}$

Final $R$ indices [I $>2 \sigma(\mathrm{I}), 15330$ reflections]

$\mathrm{R}$ indices (all data)

Type of weighting scheme used

Weighting scheme used

Max shift/error

Average shift/error

Absolute structure parameter

Largest diff. peak and hole
SHELXS-97 (Sheldrick, 1990)

Direct methods

Difference Fourier map

Difference Fourier map

SHELXL-97 (Sheldrick, 1997)

Full matrix least-squares on $\mathrm{F}^{2}$

18496 / 0 / 534

Unrestrained

1.165

$\mathrm{R} 1=0.0313, w \mathrm{R} 2=0.0489$

$\mathrm{R} 1=0.0450, w \mathrm{R} 2=0.0507$

Sigma

$w=1 / \sigma^{2}\left(\mathrm{Fo}^{2}\right)$

0.003

0.000

$-0.036(8)$

2.104 and -0.833 e. $\AA^{-3}$

\section{Special Refinement Details}

All peaks in the final difference Fourier map greater than $1 \mathrm{e}^{-} / \AA^{3}$ are within $1 \AA$ of either Pd or $S b$.

Refinement of $\mathrm{F}^{2}$ against ALL reflections. The weighted $\mathrm{R}$-factor $(w \mathrm{R})$ and goodness of fit $(\mathrm{S})$ are based on $\mathrm{F}^{2}$, conventional $\mathrm{R}$-factors $(\mathrm{R})$ are based on $\mathrm{F}$, with $\mathrm{F}$ set to zero for negative $\mathrm{F}^{2}$. The threshold expression of $\mathrm{F}^{2}>$ $2 \sigma\left(F^{2}\right)$ is used only for calculating R-factors(gt) etc. and is not relevant to the choice of reflections for refinement. $\mathrm{R}$-factors based on $\mathrm{F}^{2}$ are statistically about twice as large as those based on F, and R-factors based on ALL data will be even larger.

All esds (except the esd in the dihedral angle between two 1.s. planes) are estimated using the full covariance matrix. The cell esds are taken into account individually in the estimation of esds in distances, angles and torsion angles; correlations between esds in cell parameters are only used when they are defined by crystal symmetry. An approximate (isotropic) treatment of cell esds is used for estimating esds involving l.s. planes. 
Figure S15. (sparteine) $\mathrm{Pd}\left(\mathrm{OCH}\left(\mathrm{CF}_{3}\right) \mathrm{C}_{6} \mathrm{H}_{5}\right) \mathrm{Cl}(6)$ shown with $50 \%$ probability ellipsoids. The solvent molecules $\left(\mathrm{CH}_{2} \mathrm{Cl}_{2}\right)$ have been omitted for clarity. Crystallographic data have been deposited at the CCDC, 12 Union Road, Cambridge CB2 1EZ, UK and copies can be obtained on request, free of charge, by quoting the publication citation and the deposition number 222289 .

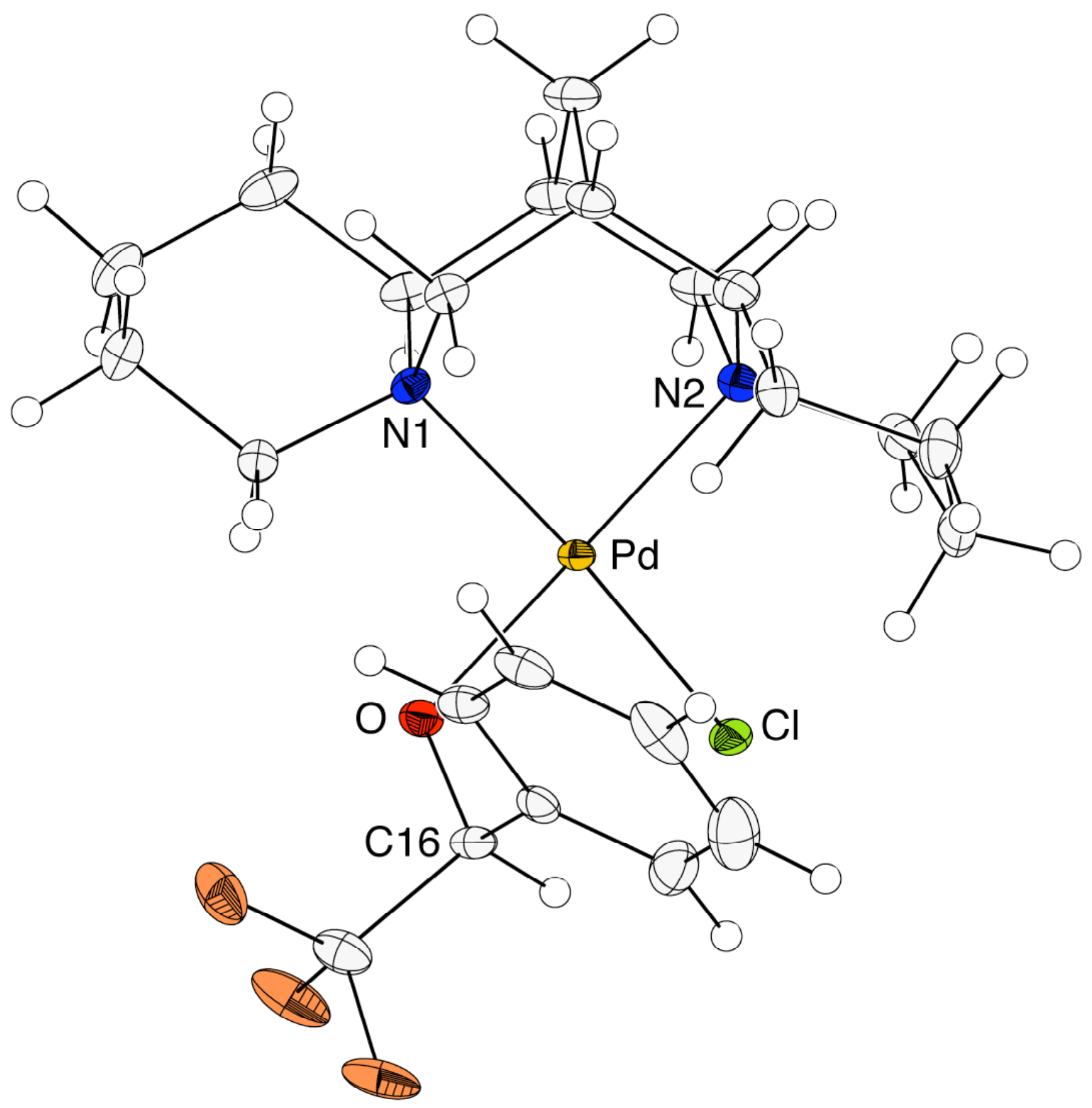


Table S09. Selected bond lengths $[\AA ̊]$ and angles for 6 (CCDC 222289).

\begin{tabular}{llll}
\hline & $2.0012(14)$ & O-Pd-N(2) & $176.27(6)$ \\
Pd-O & $2.0925(16)$ & O-Pd-N(1) & $89.78(6)$ \\
Pd-N(2) & $2.1243(17)$ & N(2)-Pd-N(1) & $88.07(6)$ \\
Pd-N(1) & $2.3316(5)$ & O(1)-Pd-Cl & $87.71(4)$ \\
Pd-Cl & $1.402(2)$ & N(2)-Pd-Cl & $95.16(4)$ \\
O-C(16) & & N(1)-Pd-Cl & $164.59(5)$ \\
& & & \\
\hline
\end{tabular}

Table S10. Crystal data and structure refinement for 6 (CCDC 222289).

Empirical formula

Formula weight

Crystallization Solvent

Crystal Habit

Crystal size

Crystal color

Preliminary Photos

Type of diffractometer

Wavelength

Data Collection Temperature

$\theta$ range for 30297 reflections used in lattice determination

Unit cell dimensions

Volume

Z

Crystal system

Space group

Density (calculated)

$\mathrm{F}(000)$

Data collection program

$\theta$ range for data collection

Completeness to $\theta=40.44^{\circ}$

Index ranges

Data collection scan type

Data reduction program
$\mathrm{C}_{23} \mathrm{H}_{32} \mathrm{ClF}_{3} \mathrm{~N}_{2} \mathrm{OPd} \cdot 2 \mathrm{CH}_{2} \mathrm{Cl}_{2}$

721.21

Dichloromethane/hexane

Block

$0.33 \times 0.33 \times 0.26 \mathrm{~mm}^{3}$

Orange

\section{Data Collection}

Rotation

Bruker SMART 1000

$0.71073 \AA \mathrm{MoK} \alpha$

100(2) K

2.35 to $38.68^{\circ}$

$\mathrm{a}=14.8633(3) \AA$

$\mathrm{b}=13.4427(3) \AA$

$\mathrm{c}=15.0189(3) \AA$

$\beta=98.5410(10)^{\circ}$

2967.54(11) $\AA^{3}$

4

Monoclinic

$\mathrm{P} 2_{1}$

$1.614 \mathrm{Mg} / \mathrm{m}^{3}$

1464

Bruker SMART v5.054

1.80 to $40.44^{\circ}$

$93.7 \%$

$-26 \leq \mathrm{h} \leq 26,-24 \leq \mathrm{k} \leq 24,-27 \leq 1 \leq 27$

$\omega$ scans at $7 \phi$ settings

Bruker SAINT v6.022 
Table S10 continued. Crystal data and structure refinement for 6 (CCDC 222289).

Reflections collected

Independent reflections

Absorption coefficient

Absorption correction

Max. and min. transmission (predicted)
79009

$33021\left[\mathrm{R}_{\mathrm{int}}=0.0654\right]$

$1.117 \mathrm{~mm}^{-1}$

None

0.7600 and 0.7094

\section{Structure solution and Refinement}

Structure solution program

Primary solution method

Secondary solution method

Hydrogen placement

Structure refinement program

Refinement method

Data / restraints / parameters

Treatment of hydrogen atoms

Goodness-of-fit on $\mathrm{F}^{2}$

Final R indices [I $>2 \sigma(\mathrm{I}), 21505$ reflections]

$\mathrm{R}$ indices (all data)

Type of weighting scheme used

Weighting scheme used

Max shift/error

Average shift/error

Absolute structure parameter

Largest diff. peak and hole
SHELXS-97 (Sheldrick, 1990)

Direct methods

Difference Fourier map

Geometric positions

SHELXL-97 (Sheldrick, 1997)

Full matrix least-squares on $\mathrm{F}^{2}$

33021 / 1 / 667

Riding

0.987

$\mathrm{R} 1=0.0401, w \mathrm{R} 2=0.0608$

$\mathrm{R} 1=0.0826, w \mathrm{R} 2=0.0669$

Sigma

$w=1 / \sigma^{2}\left(\mathrm{Fo}^{2}\right)$

0.003

0.000

$-0.036(10)$

2.072 and -1.257 e. $\AA^{-3}$

\section{Special Refinement Details}

Peaks in the difference Fourier larger than $1 \mathrm{e}^{-} / \AA^{3}$ lie near metal centers or near solvent molecules.

Refinement of $\mathrm{F}^{2}$ against ALL reflections. The weighted R-factor $(w \mathrm{R})$ and goodness of fit $(\mathrm{S})$ are based on $\mathrm{F}^{2}$, conventional R-factors $(\mathrm{R})$ are based on $\mathrm{F}$, with $\mathrm{F}$ set to zero for negative $\mathrm{F}^{2}$. The threshold expression of $\mathrm{F}^{2}>$ $2 \sigma\left(\mathrm{F}^{2}\right)$ is used only for calculating R-factors $(\mathrm{gt})$ etc. and is not relevant to the choice of reflections for refinement. $\mathrm{R}$-factors based on $\mathrm{F}^{2}$ are statistically about twice as large as those based on $\mathrm{F}$, and R-factors based on ALL data will be even larger.

All esds (except the esd in the dihedral angle between two l.s. planes) are estimated using the full covariance matrix. The cell esds are taken into account individually in the estimation of esds in distances, angles and torsion angles; correlations between esds in cell parameters are only used when they are defined by crystal symmetry. An approximate (isotropic) treatment of cell esds is used for estimating esds involving l.s. planes. 
Figure S16. ( $\alpha$-isosparteine) $\mathrm{PdCl}_{2}(\mathbf{S 0 2})$ shown with $50 \%$ probability ellipsoids. Crystallographic data have been deposited at the CCDC, 12 Union Road, Cambridge CB2 1EZ, UK and copies can be obtained on request, free of charge, by quoting the publication citation and the deposition number 223628.

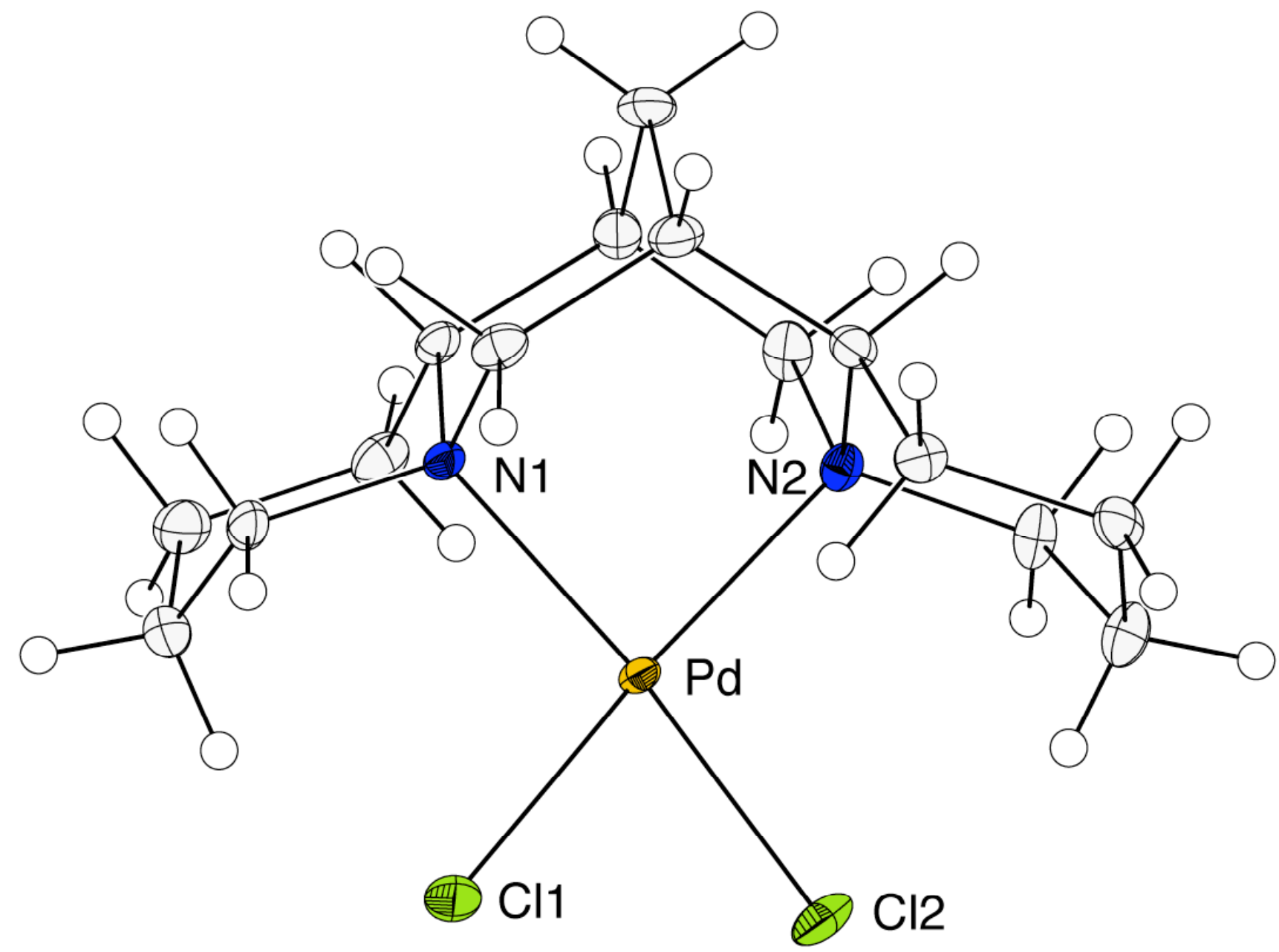

Table S11. Selected bond lengths $[\AA ̊]$ and angles for S02 (CCDC 223628).

\begin{tabular}{llll}
\hline & & & \\
$\mathrm{Pd}-\mathrm{N}(1)$ & $2.1091(11)$ & $\mathrm{N}(1)-\mathrm{Pd}-\mathrm{N}(2)$ & $87.23(4)$ \\
$\mathrm{Pd}-\mathrm{N}(2)$ & $2.1271(12)$ & $\mathrm{N}(1)-\mathrm{Pd}-\mathrm{Cl}(2)$ & $166.25(4)$ \\
$\mathrm{Pd}-\mathrm{Cl}(2)$ & $2.3140(3)$ & $\mathrm{N}(2)-\mathrm{Pd}-\mathrm{Cl}(2)$ & $95.68(3)$ \\
$\mathrm{Pd}-\mathrm{Cl}(1)$ & $2.3275(4)$ & $\mathrm{N}(1)-\mathrm{Pd}-\mathrm{Cl}(1)$ & $94.81(3)$ \\
& & $\mathrm{N}(2)-\mathrm{Pd}-\mathrm{Cl}(1)$ & $163.54(3)$ \\
& & $\mathrm{Cl}(2)-\mathrm{Pd}-\mathrm{Cl}(1)$ & $86.205(15)$ \\
\hline
\end{tabular}


Table S12. Crystal data and structure refinement for S02 (CCDC 223628).

Empirical formula

Formula weight

Crystallization Solvent

Crystal Habit

Crystal size

Crystal color

Preliminary Photos

Type of diffractometer

Wavelength

Data Collection Temperature

$\theta$ range for 24049 reflections used

in lattice determination

Unit cell dimensions

Volume

Z

Crystal system

Space group

Density (calculated)

$\mathrm{F}(000)$

Data collection program

$\theta$ range for data collection

Completeness to $\theta=44.97^{\circ}$

Index ranges

Data collection scan type

Data reduction program

Reflections collected

Independent reflections

Absorption coefficient

Absorption correction

Max. and min. transmission (predicted)
$\mathrm{C}_{15} \mathrm{H}_{26} \mathrm{Cl}_{2} \mathrm{~N}_{2} \mathrm{Pd}$

411.68

Dichloromethane

Fragment

$0.39 \times 0.24 \times 0.22 \mathrm{~mm}^{3}$

Maroon

\section{Data Collection}

Rotation

Bruker SMART 1000

$0.71073 \AA ̊ \mathrm{MoK} \alpha$

100(2) K

2.22 to $44.96^{\circ}$

$\mathrm{a}=9.2815(3) \AA$

$\mathrm{b}=11.4873(4) \AA$

$\mathrm{c}=15.1073(5) \AA$

1610.73(9) $\AA^{3}$

4

Orthorhombic

$\mathrm{P} 2{ }_{1} 2_{1} 2_{1}$

$1.698 \mathrm{Mg} / \mathrm{m}^{3}$

840

Bruker SMART v5.054

2.23 to $44.97^{\circ}$

$94.4 \%$

$-17 \leq \mathrm{h} \leq 16,-22 \leq \mathrm{k} \leq 20,-28 \leq 1 \leq 29$

$\omega$ scans at $7 \phi$ settings

Bruker SAINT v6.45

44470

$11830\left[\mathrm{R}_{\mathrm{int}}=0.0673\right]$

$1.476 \mathrm{~mm}^{-1}$

None

0.7372 and 0.5968 
Table S12 continued. Crystal data and structure refinement for S02 (CCDC 223628).

Structure solution and Refinement

Structure solution program

Primary solution method

Secondary solution method

Hydrogen placement

Structure refinement program

Refinement method

Data / restraints / parameters

Treatment of hydrogen atoms

Goodness-of-fit on $\mathrm{F}^{2}$

Final $\mathrm{R}$ indices [I $>2 \sigma(\mathrm{I}), 9732$ reflections]

$\mathrm{R}$ indices (all data)

Type of weighting scheme used

Weighting scheme used

Max shift/error

Average shift/error

Absolute structure parameter

Largest diff. peak and hole
SHELXS-97 (Sheldrick, 1990)

Direct methods

Difference Fourier map

Difference Fourier map

SHELXL-97 (Sheldrick, 1997)

Full-matrix least-squares on $\mathrm{F}^{2}$

11830 / 0 / 285

Unrestrained

1.139

$\mathrm{R} 1=0.0317, w \mathrm{R} 2=0.0525$

$\mathrm{R} 1=0.0452, w \mathrm{R} 2=0.0542$

Sigma

$w=1 / \sigma^{2}\left(\mathrm{Fo}^{2}\right)$

0.004

0.000

$-0.042(13)$

1.557 and -1.497 e. $\AA^{-3}$

\section{Special Refinement Details}

Refinement of $\mathrm{F}^{2}$ against ALL reflections. The weighted R-factor $(w \mathrm{R})$ and goodness of fit $(\mathrm{S})$ are based on $\mathrm{F}^{2}$, conventional R-factors $(\mathrm{R})$ are based on $\mathrm{F}$, with $\mathrm{F}$ set to zero for negative $\mathrm{F}^{2}$. The threshold expression of $\mathrm{F}^{2}>$ $2 \mathrm{~s}\left(\mathrm{~F}^{2}\right)$ is used only for calculating R-factors $(\mathrm{gt})$ etc. and is not relevant to the choice of reflections for refinement. $\mathrm{R}$-factors based on $\mathrm{F}^{2}$ are statistically about twice as large as those based on $\mathrm{F}$, and R-factors based on ALL data will be even larger.

All esds (except the esd in the dihedral angle between two l.s. planes) are estimated using the full covariance matrix. The cell esds are taken into account individually in the estimation of esds in distances, angles and torsion angles; correlations between esds in cell parameters are only used when they are defined by crystal symmetry. An approximate (isotropic) treatment of cell esds is used for estimating esds involving l.s. planes. 